\title{
A!
}

This is an electronic reprint of the original article.

This reprint may differ from the original in pagination and typographic detail.

Thiel, Daniel; Blume, Fabian; Jäger, Christina; Deska, Jan

\section{Chloroperoxidase-Catalyzed Achmatowicz Rearrangements}

Published in:

European Journal of Organic Chemistry

DOI:

10.1002/ejoc.201800333

Published: 07/06/2018

Document Version

Peer reviewed version

Published under the following license:

Unspecified

Please cite the original version:

Thiel, D., Blume, F., Jäger, C., \& Deska, J. (2018). ChloroperoxidaseCatalyzed Achmatowicz Rearrangements. European Journal of Organic Chemistry, 20, 2717-2725. https://doi.org/10.1002/ejoc.201800333

This material is protected by copyright and other intellectual property rights, and duplication or sale of all or part of any of the repository collections is not permitted, except that material may be duplicated by you for your research use or educational purposes in electronic or print form. You must obtain permission for any other use. Electronic or print copies may not be offered, whether for sale or otherwise to anyone who is not an authorised user. 


\title{
Chloroperoxidase-catalyzed Achmatowicz Rearrangements
}

\author{
Daniel Thiel, ${ }^{[a, \pm]}$ Fabian Blume, ${ }^{[a]}$ Christina Jäger, ${ }^{[a]}$ and Jan Deska*[a]
}

Abstract: Chloroperoxidase from Caldariomyces fumago catalyzes the selective oxidation of furfuryl alcohols in an Achmatowicz-type ring expansion. In combination with glucose oxidase as oxygen-activating biocatalyst, a purely enzymatic, aerobic protocol for the synthesis of 6-hydroxypyranone building blocks is obtained. Thanks to an only modest stereochemical bias of the oxygenating heme protein, optically active alcohols of either configuration are converted without a significant mismatch opening up opportunities for enantioselective multienzymatic cascades. Balancing the oxidase-driven aerobic activation, extended enzyme half-lifes and productive conversion of poorly soluble and slowly reacting substrates can be achieved with high yields of the six-membered O-heterocycles.

\section{Introduction}

Over the past decades, the Achmatowicz-type ring expansion ${ }^{[1]}$ the oxidative conversion of $\alpha$-heterosubstituted furfuryl derivatives to six-membered $\mathrm{O}$ - or $\mathrm{N}$-heterocyclic building blocks - has become a valuable tool in modern synthetic organic chemistry. ${ }^{[2-5]}$ Both the easy access to suitable heteroaromatic Achmatowicz substrates as well as the broad range of follow-up chemistry offered by the pyranone or piperidinone products make this transformation an attractive instrument in the synthesis of complex natural products and biologically active agents. While the original procedures by Achmatowicz ${ }^{[1,6]}$ and Lefebvre ${ }^{[7]}$ still relied on the use of stoichiometric oxidants such as bromine or metachloroperbenzoic acid, over the years multiple powerful variations based on e.g. metal catalysis, photoactivation and electrochemistry have been brought forward providing additional selectivities and broader applicability. ${ }^{[8]}$ In light of milder and environmentally more benign approaches towards the oxidative ring rearrangement of the furfuryl derivatives, recently the use of enzymes as biological catalyst has been brought into the focus (Scheme 1). Here, both the groups of Beifuss, ${ }^{[9]}$ and of Rutjes and Hollmann ${ }^{[10]}$ have been successful in the development of bioinduced protocols relying on the biocatalytic generation of diffusible oxidizing species from the interaction of an oxidoreductase with a suitable redox mediator. In the first enzyme-driven report, laccases in combination with TEMPObased redox moderators act as catalytic principle in an aerobic ring expansion to give substituted pyranones utilizing air as terminal oxidant. Similarly to the original $\mathrm{Br}_{2}$-based method by

[a] Dr. D. Thiel, Dipl.-Chem. F. Blume, Christina Jäger, Prof. Dr. J. Deska

Department of Chemistry and Materials Science, Aalto-yliopisto Kemistintie 1, 02150 Espoo, Finland

E-mail: jan.deska@aalto.fi www.deskalab.com

[†] Current affiliation: CAT Catalytic Center, RWTH Aachen University, Worringerweg 2, 52074 Aachen, Germany

Supporting information for this article is given via a link at the end of the document.
Achmatowicz, halonium species generated by the catalytic conversion of hydrogen peroxide as terminal oxidant and bromide through a vanadium-dependent haloperoxidase promote the oxidative furan cleavage that ultimately leads to the sixmembered heterocycles and its efficacy has been demonstrated for the synthesis of both pyranones and piperidinones. In addition to these mediated processes, in 2014 our group established a novel protocol exploiting the oxygenating properties of hemedependent peroxidases in order to catalyze Achmatowicz-type reactions in a truly biocatalytic manner exploiting a direct proteinfuran interaction. ${ }^{[11]}$ In combination with an oxidase and a cheap sacrificial reductant such as sugars or alcohols for the controlled in situ generation of hydrogen peroxide, the aerobic rearrangement of furfuryl alcohols is achieved. ${ }^{[12]}$

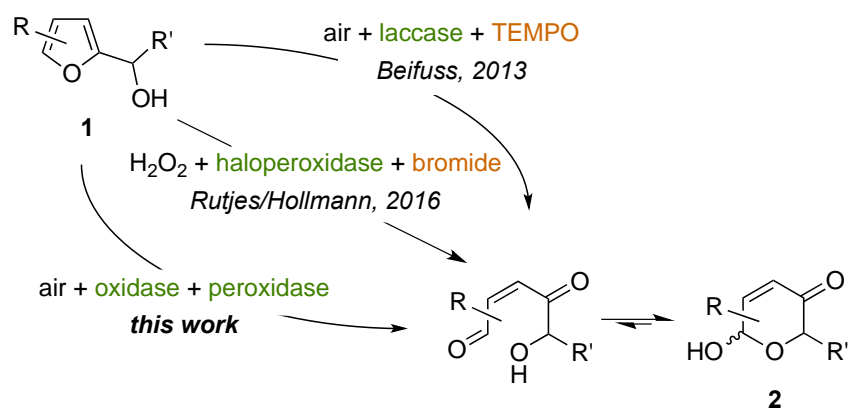

Scheme 1. Biocatalytic approaches for the oxidative ring expansion of furfuryl alcohols.

In this paper, we disclose the results of an in-depth study on the initial development and the improvement of an enzyme-catalyzed Achmatowicz protocol based on chloroperoxidase from Caldariomyces fumago, including stereochemical investigations on the enantioselectivity of the heme protein and an extended substrate scope analysis. Additionally, a mediated protocol exploiting biocatalytically generated peracetic acid is presented as alternative to overcome the current structural limitations of the wild-type chloroperoxidase. 


\section{Results and Discussion}

\section{Methodological Studies}

Our study towards an enzyme-catalyzed version of the well established Achmatowicz rearrangement commenced with the identification of biological systems that would resemble the key step in the transformation, that is, the oxygenative cleavage of furans to form ketoenal intermediates (Scheme 1). ${ }^{[13]}$ Here, investigations on the in vivo degradation of furans by cytochrome P450 monooxygenases indicated that heme-dependent oxygenation biocatalysts might provide the required reactivity to be utilized in the title reaction. ${ }^{[14,15]}$ As relatively cheap commercial alternative to the P450s, we envisaged that heme peroxidases could potentially serve this purpose, and initial studies aimed to elucidate the oxygenating abilities of a set of peroxidases with regard to the conversion of 1 -furylethanol (1a). Owing to structural differences in the active site, particularly the nature of the axial heme ligand, only a few peroxidases actually behave in a cytochrome P450-like manner and hence, ${ }^{[16,17]}$ it was no surprise that classical peroxidases such as soybean-, horseradish- or lactoperoxidase, fueled by a glucose/glucose oxidase $\mathrm{H}_{2} \mathrm{O}_{2}$ production system, ${ }^{[18]}$ did not exhibit major activity in the oxidation of $1 \mathrm{a}$ and only in the case of horseradish peroxidase, traces of the desired pyranone 2a were detected after $24 \mathrm{~h}$ (Scheme 2). On the other hand, employing the same oxidase-based $\mathrm{H}_{2} \mathrm{O}_{2}$ delivery tool but changing the peroxidase to a chloroperoxidase from Caldariomyces fumago (CPO) that acts as peroxidase-P450 functional hybrid, ${ }^{[19,20]}$ almost full conversion was observed already after $3 \mathrm{~h}$ with a significant amount of $2 \mathrm{a}(51 \%)$ being

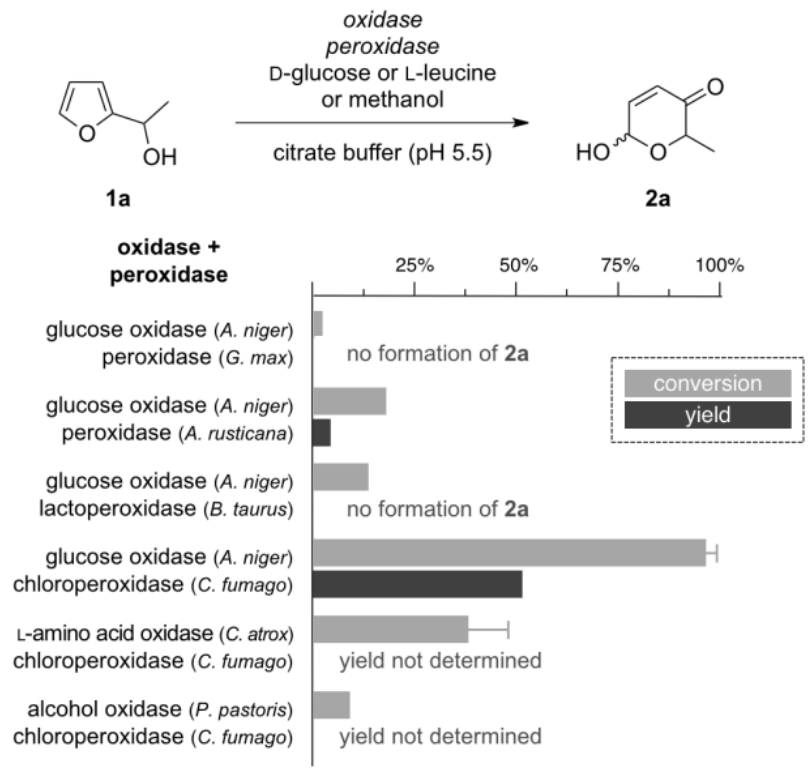

Scheme 2. Peroxidase and oxidase screening formed. Considering the structural similarities between the sugar substrate of the glucose oxidase and the Achmatowicz pyranones, it was first assumed that oxidase activity on the initially formed lactol 2a might attribute to the discrepancy of conversion and yields under the non-optimized reaction conditions. However, spectroscopic analysis of the crude reaction mixtures did not show any traces of the $\mathbf{2 a}$-derived lactone as side product. Also, a photospectrometric oxidase assay coincubating $\mathbf{2 a}$ and glucose oxidase (with horseradish peroxidase and ABTS as reporter) remained silent, thus ruling out any undesired cross-reactivity between the sugar oxidase and the sugar-like hydroxypyranone products. Nevertheless, also other oxidase/reductant systems were tested and while both leucine/amino acid oxidase and methanol/alcohol oxidase did not match the outcome of the glucose oxidase-driven protocol, modification of oxidase loading or the reaction environment might give rise to productive Achmatowicz systems in those cases as well.

Yet, considering the generally low cost of both glucose and the glucose oxidase (GOx), subsequent optimization studies were pursued on this most successful initial screening hit. Variation of the $\mathrm{pH}$ of the reaction medium (aqueous citrate or phosphate buffers) revealed a rather wide plateau between 4.5 and 6.5 with greater $90 \%$ conversion of $1 \mathrm{a}$ with $2 \mathrm{~h}$, and a sharp loss of oxygenating power at neutral $\mathrm{pH}$ (Figure 1a, left). In the context of $\mathrm{pH}$ optimization, it is important to pay attention not only to the enzyme activity but also to the stability of the reaction substrates, in particular with regard to their stereochemical integrity. Therefore, enantiomerically pure $(R)$-1a was also incubated in absence of any biocatalyst for $24 \mathrm{~h}$ after which the optical activity of the recovered starting material was determined. Clearly, due to the benzylic situation of the alcohol, racemization can become an issue at $\mathrm{pH}$ values less than 5.5 where slow epimerization is taking place (Figure 1a, right). Consequently, the optimal operation window for the CPO-mediated ring expansion of furfuryl alcohols can be set to $\mathrm{pH} 5.5-6.5$.

Next, the influence of cosolvents was addressed in order to identify suitable solubilizing additives enabling high concentrations of the more or less lipophilic furfuryl substrates (Figure 1b). To our delight, addition of $10 \%$ tert-butanol to the reaction medium did not affect the enzymes' activity and full conversion of 1a was achieved after $3 \mathrm{~h}$. Yet, in contrast to the purely aqueous medium, pyranone $\mathbf{2 a}$ was isolated in greatly improved $82 \%$ yield after reaction in the buffer/ $\mathrm{tBuOH}$ mixture, an effect that could be later attributed to the improved stability of Achmatowicz-type pyranones in the medium (pure buffer: $\mathrm{t}_{1 / 2} \mathbf{2}(\mathbf{2} \mathbf{a})$ $=11.9 \mathrm{~h}$; buffer $\left./ \mathrm{tBuOH}: \mathrm{t}_{1 / 2}(\mathbf{2 a})=40.7 \mathrm{~h}\right)$. In this medium, the reaction could also be significantly scaled to a total of $50 \mathrm{mmol}$ of $1 \mathrm{a}$ at increased concentration (50 $\mathrm{mM})$ and reduced CPO loading $(200 \mathrm{U} / \mathrm{mmol})$ with a yield of $76 \%$. Acetone as cosolvent exhibited a similar effect although the activity was slightly reduced, reaching conversion levels $>90 \%$ only after $6 \mathrm{~h}$. Addition of DMSO or acetonitrile on the other hand resulted in modest inhibition of the 
reaction and in biphasic reaction media such as buffer/heptane mixtures, no reaction was observed.

a $\mathrm{pH}$ influence on enzyme activity \& stereochemical integrity

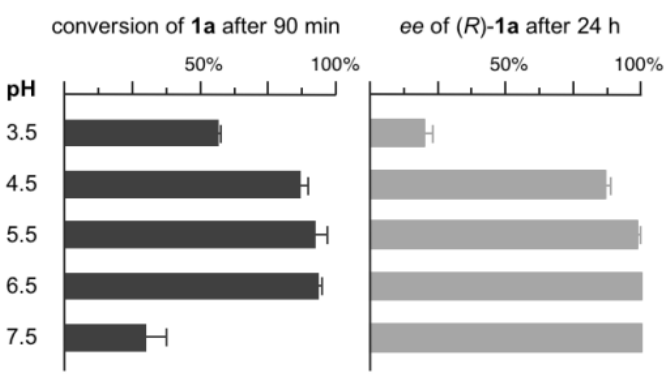

b cosolvent influence on enzyme activity \& product selectivity

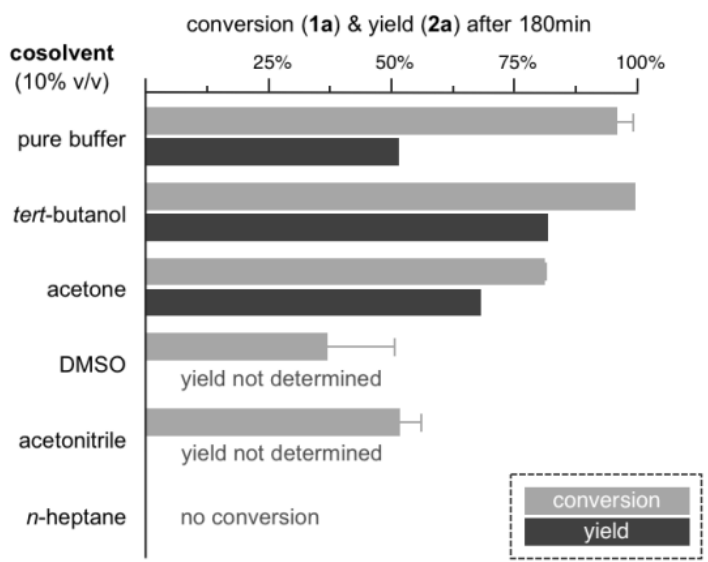

Figure 1. Optimization of reaction parameters for the CPO-mediated oxidative ring expansion of 1-(2-furyl)ethanol (1a).

\section{Stereochemical Investigations}

With an effective biocatalytic Achmatowicz system in hand, next the stereoselectivity of the chloroperoxidase towards different kinds of furans was studied. Starting from racemic 1-(2furyl)alkanols with varying chain length, branching, and functionalization patterns, the extent of enantiodiscrimination in kinetic resolutions of the furans was recorded at low conversion rates (Table 1). In all cases, the tested furan were transformed to the corresponding ring expanded heterocycles and a certain enantioenrichment of the remaining alcohols was observed. Yet the enantioselectivity $E\left(k_{(R)}\right.$ vs $\left.k_{(S)}\right)$ proved to be mediocre at best. Moreover, there was no obvious trend with regard to steric bias of the side chain as both the slim methyl-substituted furfuryl alcohol 1a as well as the bulky tert-butyl derivative $\mathbf{1 h}$ exhibited $E$ values of less than 3 (Table 1 , entry $1 \& 8$ ). The most effective kinetic resolution took place with the homoallylic alcohol $1 \mathrm{e}$ but with relative rates of approximately 10:1 favoring the conversion of the $(R)$-enantiomer (Table 1 , entry 5 ), synthetically useful optical purities remain elusive. Hence, the production of enantioenriched pyranones by enzymatic resolution must be considered unpractical unless further optimization of the biocatalyst by directed evolution could deliver more specific chloroperoxidase variants.

Table 1. Enantiodiscrimination in the oxidative conversion of racemic furfuryl alcohols.

\begin{tabular}{|c|c|c|c|c|}
\hline$\langle 0$ & $\begin{array}{r}\begin{array}{r}\text { chloroperc } \\
\text { glucose }\end{array} \\
\begin{array}{r}\text { D-glucose } \\
\text { citrate } \\
30\end{array}\end{array}$ & $\underset{\% \text { \% v/v) }}{\stackrel{\text { fumago }}{\text { niger) }}}$ & $\underbrace{R}_{\overline{\bar{O}}}$ & $(R)-2$ \\
\hline Entry ${ }^{[a]}$ & $R$ & $\begin{array}{l}\text { conversion } \\
{[\%]^{[b]}}\end{array}$ & $\begin{array}{l}e e(1) \\
{[\%]^{[b]}}\end{array}$ & $\begin{array}{l}E \\
{\left[k_{(R)} / k_{(S)}\right]^{[c]}}\end{array}$ \\
\hline 1 & methyl (1a) & 16 & 6 & 2.3 \\
\hline 2 & ethyl (1b) & 16 & 9 & 3.0 \\
\hline 3 & n-propyl (1c) & 13 & 9 & 4.4 \\
\hline 4 & vinyl (1d) & 11 & 9 & 6.9 \\
\hline 5 & allyl (1e) & 12 & 11 & 10.4 \\
\hline 6 & $i$-propyl (1f) & 18 & 11 & 3.3 \\
\hline 7 & i-butyl (19g) & 12 & 10 & 7.2 \\
\hline 8 & $t$-butyl (1h) & 8 & 4 & 2.8 \\
\hline 9 & phenyl (1i) & 12 & 8 & 4.2 \\
\hline 10 & $\mathrm{CH}_{2} \mathrm{CO}_{2} \mathrm{Et}(\mathbf{1} \mathbf{j})$ & 17 & 4 & 1.5 \\
\hline
\end{tabular}

[a] Reaction conditions: alcohol 1 (25 $\mu \mathrm{mol})$, D-glucose $(125 \mu \mathrm{mol})$, chloroperoxidase $(25 \mathrm{U})$, glucose oxidase $(25 \mathrm{U})$, citrate buffer $(2.25 \mathrm{~mL}, 0.1 \mathrm{M}$, $\mathrm{pH} 5.5), \mathrm{tBuOH}(0.25 \mathrm{~mL}), 30^{\circ} \mathrm{C}$. Yields determined after purification by column chromatography. [b] Conversions and optical purities determined by chiral gas chromatography using bromobenzene as internal standard. [c] Enantioselectivities calculated according to $\mathrm{Sih}$ et al. ${ }^{[21]}$

\section{Substrate Scope and Limitations}

On the other hand, the lack of substantial enantiodiscrimination by the chloroperoxidase can also be seen as a positive feature of the biocatalytic method since limitations to certain stereoisomers due to matched/mismatched situations become less likely. Considering the general disadvantage of kinetic resolution approaches to be yield-limited to a maximum of $50 \%$ of optically pure material, alternative pathways to address enantioenriched pyranone products by combining the stereoselective synthesis of furfuryl alcohols with the subsequent aerobic rearrangement appear highly attractive. In particular, the ketoreductase-mediated alcohol synthesis by reduction of the 
corresponding furyl ketones opens up great opportunities for an effective, fully enzymatic route to these synthetically valuable building blocks. Based on a previously reported method utilizing two commercial alcohol dehydrogenases (ADH200 \& ADH 030 from evoCatal) as asymmetric reduction catalyst, ${ }^{[11]}$ a set of optically active furylcarbinols was prepared and tested under the optimized conditions for the Achmatowicz-type ring expansion (Table 2). Gratifyingly, both antipodes of the model substrate 1a were converted smoothly and the enantiomeric pyranones $(R)$-2a and $(S)-2$ a were not only isolated in high yields but also with complete conservation of the stereogenic information (Table 2, entry $1 \& 2$ ). Also the homologues $(R)-2 \mathbf{b}$ and $(R)-\mathbf{2 c}$ could be obtained in reasonable yields (Table 2 , entry $3 \& 4$ ), and notably, further improvement of optical purity was observed starting from just moderately enantioenriched 1c (from $95 \%$ ee to $98 \%$ ee of 2c). Moreover, the CPO-mediated procedure exhibited a high functional group tolerance, not only accepting ester- or chlorosubstituted furylcarbinols (Table 2, entry $6 \& 7$ ) but more importantly, providing selectivity in the furan oxidation in presence of oxidation-labile moieties such as olefins and primary

Table 2. Oxidative ring expansion of optically active furfuryl alcohols.

\begin{tabular}{|c|c|c|c|c|}
\hline 3 & $\overbrace{(R)-1}^{\mathrm{R}}$ & $\begin{array}{l}\text { eroxidase (C. fumago) } \\
\text { se oxidase (A. niger) } \\
\text { se, } t \mathrm{BuOH}(10 \% \mathrm{v} / \mathrm{v}) \\
\text { te buffer }(\mathrm{pH} 5.5) \\
30^{\circ} \mathrm{C}, 2 \mathrm{~h}\end{array}$ & & )-2 \\
\hline Entry ${ }^{[a]}$ & $\mathrm{R} / \mathrm{R}^{\prime}$ & $\begin{array}{l}e e(1) \\
{[\%]^{[b]}}\end{array}$ & $\begin{array}{l}\text { yield }(\mathbf{2}) \\
{[\%]}\end{array}$ & $\begin{array}{l}\text { ee (2) } \\
{[\%]^{[c]}}\end{array}$ \\
\hline 1 & $\mathrm{H}$ / methyl (1a) & 99 & 83 & 99 \\
\hline 2 & $\mathrm{H} /$ methyl (ent-1a) & 99 & 81 & 99 \\
\hline 3 & H / ethyl (1 $\mathbf{b})$ & 99 & 77 & 99 \\
\hline 4 & H / n-propyl (1c) & 95 & 53 & 98 \\
\hline 5 & H / allyl (1e) & 95 & 65 & 98 \\
\hline 6 & $\mathrm{H} / \mathrm{CH}_{2} \mathrm{CO}_{2} \mathrm{Et}(\mathbf{1} \mathbf{j})$ & 99 & 64 & 99 \\
\hline 7 & $\mathrm{H} / \mathrm{CH}_{2} \mathrm{Cl}(\mathbf{1 k})$ & 99 & 68 & 99 \\
\hline 8 & $\mathrm{H} / \mathrm{CH}_{2} \mathrm{OH}(\mathbf{1 I})$ & 99 & 31 & 99 \\
\hline 9 & H / ethynyl (1m) & 99 & 0 & - \\
\hline 10 & methyl / methyl (1n) & 99 & 0 & - \\
\hline
\end{tabular}

[a] Reaction conditions: alcohol 1 (0.5 mmol), D-glucose $(2.5 \mathrm{mmol})$, chloroperoxidase $(0.5 \mathrm{kU})$, glucose oxidase $(0.5 \mathrm{kU})$, citrate buffer $(45 \mathrm{~mL}$, $0.1 \mathrm{M}, \mathrm{pH} 5.5), \mathrm{tBuOH}(5 \mathrm{~mL}), 30^{\circ} \mathrm{C}$. Yields determined after purification by column chromatography. [b] Optical purities determined by chiral gas chromatography. alcohols (Table 2, entry $5 \& 8$ ). The propargylic alcohol $\mathbf{1 m}$, however, could not be transformed to the corresponding pyranone. Subsequent coincubation studies with 1a revealed that $1 \mathrm{~m}$, and other alkyne additives, exhibit inhibitory properties on the CPO-catalyzed reaction. The core-substituted alcohol $\mathbf{1 n}$ on the other hand did not affect the conversion of other substrates in a negative way, yet, also here the CPO/GOx system failed to provide the 2,6-dimethylpyranone $\mathbf{2 n}$.

Despite the mostly convincing yields, optical purities and the good functional group tolerance of the CPO-catalyzed Achmatowicz protocol, the stereochemical investigations and substrate scope studies also revealed some issues related to conversion rates of highly lipophilic long-chain or branched aliphatic furylalkanols in particular. Hereby, the decline in reaction rates, and consequently in product yields, follows a very clear trend along the homologous series from the rapidly reacting furylethanol (1a) to the virtually non-reactive furylheptanol (1q) (Scheme 3). Likewise, incorporation of branched aliphatics results in severely diminished pyranone yields ranging from mediocre $34 \%$ for the isopropyl derivative (2f) to only trace amounts of the butyl derivatives $\mathbf{2} \mathbf{g}$ and $\mathbf{2 h}$. While unfavorable sterics might be a reason for this effect, the observation that the similarly bulky ester-functionalized substrate $\mathbf{1 j}$ performed well in the CPOmediated ring expansion points towards a different explanation where the poor solubility of substrates such as $\mathbf{1 g}$ or $\mathbf{1 q}$ in the aqueous medium could account for their sluggish conversion. Unfortunately, increased concentrations of $\mathrm{tBuOH}$, that would improve the solubility of lipophilic substrates in the reaction mixture, in turn resulted in rapid enzyme inhibition. Thus, further studies targeting suitable solubilizing additives seem to be necessary as one option to widen the scope of the reaction to long-chain furylcarbinols. 


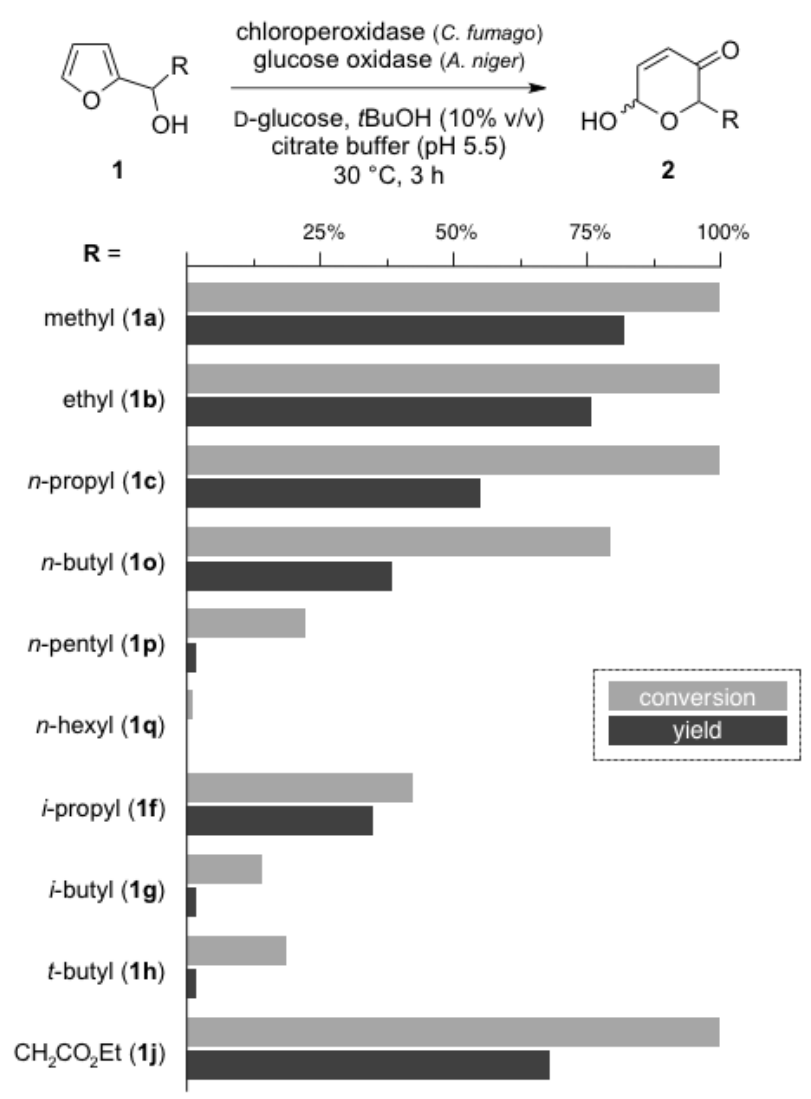

Scheme 3. Influence of chain length and branching on the CPO-mediated Achmatowicz rearrangement.

In addition to solubility issues, with a low rate of conversion of the sterically more biased, challenging furfuryl alcohol substrates by the chloroperoxidase, apparently the accumulation of hydrogen peroxide produced by the glucose oxidase at constant rates might become an issue as bleaching of the heme protein at high concentrations of $\mathrm{H}_{2} \mathrm{O}_{2}$ could account for an enzyme inhibition and the low overall turnover to the desired pyranones. ${ }^{[22,23]}$ In order to investigate this hypothesis, furan $\mathbf{1 f}$ was incubated with the CPO/GOx enzyme mix, with the amount of oxidase relative to the peroxidase (units of GOx vs units of $\mathrm{CPO}$ ) being systematically reduced (Scheme 4 ). The comparison between conversion values after $3 \mathrm{~h}$ and $24 \mathrm{~h}$ indicates how strongly the biocatalytic system is impaired by the different rates of $\mathrm{H}_{2} \mathrm{O}_{2}$ production. At high peroxide generation rates ( $\mathrm{GOx} / \mathrm{CPO}$ $>1$ ), the peroxidase obviously suffers a rapid deactivation resulting in low consumption of 1f. Since no additional turnover is observed between the first and second measurements, it can be assumed that complete CPO inhibition is taking place within the first three hours. By lowering the oxidase loading, significantly higher conversions up to greater $90 \%$ are achieved and the lifetime of the peroxidase is considerably improved. Even at a 100 -fold reduction of the GOx, oxidation of the furfuryl alcohol proceeds slowly and after $24 \mathrm{~h}, 84 \%$ conversion is reached. A subtle balancing of the oxygen-activating and the oxygen-transfer biocatalyst should thus allow for productive enzymatic Achmatowicz rearrangements even of slowly reacting furfuryl substrates.

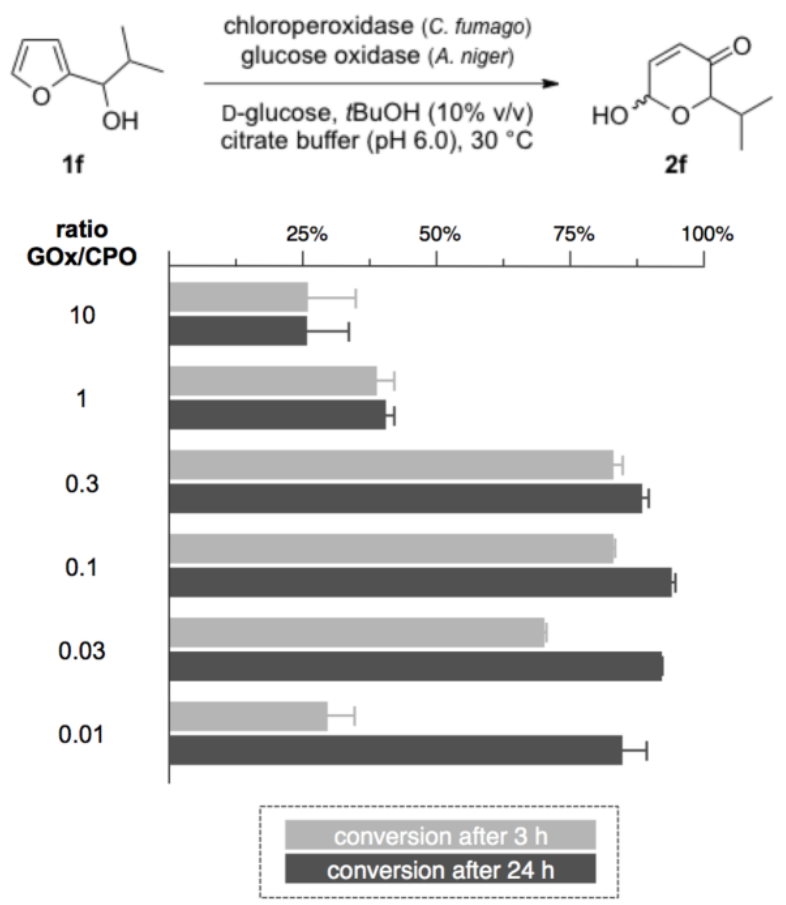

Scheme 4. Balancing of oxidase and peroxidase activity.

The modified CPO-based Achmatowicz system was subsequently tested on a set of particularly challenging furans that exhibited very low yields under the originally applied conditions (Scheme 5). On a preparative scale, the yields of both the isopropyl- (2f) and the isobutyl-substituted (2g) pyranone were significantly increased by exploiting an aerobic ring expansion protocol that was rate-limited by the reduced GOx loading $(\mathrm{GOx} / \mathrm{CPO}=0.03)$. Utilizing enantioenriched $1 f(97 \%$ ee $)$, the desired pyranone was obtained in optically pure form, clearly indicating that despite the extended reaction times, racemization of the furfuryl alcohols is not an issue. Notably, under identical conditions, also highly problematic substrates such as the tertiary alcohol 1r or the core-substituted 3-methylfurfuryl alcohol 1s were oxidatively converted to the corresponding pyranones $\mathbf{2 r}$ and $\mathbf{2 s}$, respectively, achieving moderate to very high yields after a reaction time of $18 \mathrm{~h}$. 


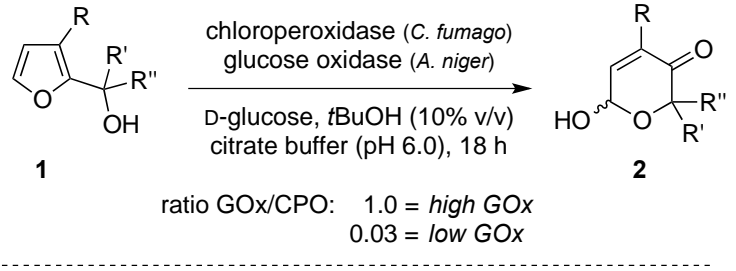<smiles>CC(C)C1OC(O)C=CC1=O</smiles>

$2 f$

high GOx: $34 \%$ low GOx: $86 \%$<smiles>CC(C)CC1O[C@H](O)C=CC1=O</smiles>

2g

\section{high GOx: $14 \%$} low GOx: $56 \%$

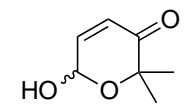

$2 r$

high GOx: $6 \%$ low GOx: $87 \%$<smiles>CC1=C[C@@H](O)OCC1=O</smiles>

2s

high GOx: $<5 \%$ low GOx: $46 \%$

Scheme 5. Optimization towards slowly reacting furfuryl substrates.

\section{Alternative Systems}

While the peroxidase/oxidase system for the biocatalytic ring expansion of furanols proved to be effective for a wide range of substrates with little to no bias towards existing stereogenic elements, the structural limitation regarding chain length and furan core substitution prompted us to reconsider alternative systems that would be independent on a productive active site binding of the furans. Here, the original protocol by Lefebvre utilizing peracids as oxidant for the rearrangement ${ }^{[5]}$ reaction served as the template for an enzyme cascade design providing a pathway for the catalytic generation of peracetic acid as diffusible redox mediator. Replacement of the peroxidase biocatalyst by a lipase (from Candida antarctica type B) rendered a system where glucose oxidase provided hydrogen peroxide to be used by the lipase to catalyze the perhydrolysis of acetic acid (from an acidic acetate buffer, $\mathrm{pH} 4.5) .{ }^{[11]}$ To our delight, 1-(5methylfuryl)ethanol (1n), previously not affected by the peroxidase/oxidase treatment, was converted smoothly under these modified conditions and gave rise to the desired 2,6dimethylpyranone $\mathbf{2 n}$ in moderate yield (Scheme 6).

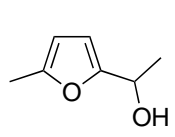

$1 n$

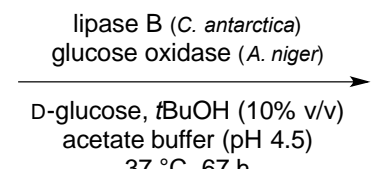

$37^{\circ} \mathrm{C}, 67 \mathrm{~h}$

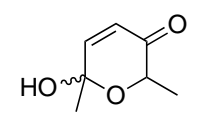

2n, $41 \%$

Scheme 6. Aerobic ring expansion of the core-substituted furan $1 \mathbf{x}$ by a oxidase/lipase couple.

Considering the relatively long reaction times and an unfavorable $\mathrm{pH}$ profile of the aqueous perhydrolysis approach with regard to furanol racemization issues, we envisaged that the unique ability of lipases to perform in non-aqueous reaction media might be of benefit in the further optimization process. Moving away from an aerobic protocol based on the oxidase-mediated activation of aerial oxygen, the robustness of the hydrolase enzyme towards both high $\mathrm{H}_{2} \mathrm{O}_{2}$ concentrations and organic solvents was expected to give rise to a simplified system. Consequently, immobilized C. antarctica lipase B was used in ethyl acetate providing good solubility for all tested furfuryl alcohols. Upon addition of aqueous hydrogen peroxide, the perhydrolysis activity of the lipase delivered the required peracid and smooth conversion to the desired pyranones was observed (Scheme 7a). Moderate to mainly good yields were achieved for a series of furan substrates that proved to be inert to the chloroperoxidase methodology. ${ }^{[24]}$ In addition, the use of a peracetic acid mediator system also allowed for a productive azaAchmatowicz rearrangement of the furyl carbamate $\mathbf{3}$ giving rise to piperidinone 4 in $65 \%$ yield (Scheme $7 b$ ).

a oxa-Achmatowicz

lipase B (C. antarctica)

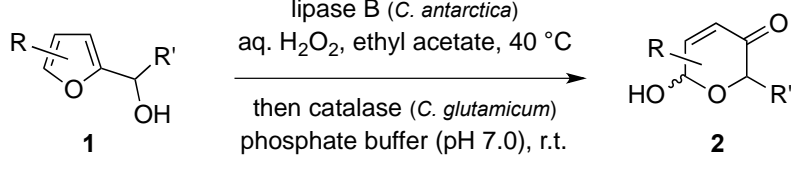<smiles>CC1OC(C)(O)C=CC1=O</smiles><smiles>CC1=C[C@@H](O)OC(C)C1=O</smiles><smiles>CCCCCCC1O[C@H](O)C=CC1=O</smiles>

2n, $74 \%$

2t, $56 \%$

$2 q, 75 \%$

b aza-Achmatowicz

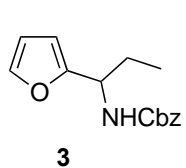

lipase $B(C$. antarctica) aq. $\mathrm{H}_{2} \mathrm{O}_{2}$, ethyl acetate, $40^{\circ} \mathrm{C}$

then catalase (C. glutamicum) phosphate buffer $(\mathrm{pH} 7.0)$, r.t.<smiles>CCC1C(=O)C=C[C@@H](O)N1C(=O)O[Na]</smiles>

Scheme 7. Lipase-mediated oxa- and aza-Achmatowicz-type ring expansions.

\section{Conclusions}

In summary, the commercial chloroperoxidase from Caldariomyces fumago exhibits high activity and a broad substrate scope in the oxidative ring expansion of furfuryl alcohols. Thanks to the absence of significant enantiodiscrimination of the 
heme protein, optically active substrates can be converted to the corresponding enantioenriched pyranones with high effectivity independent on their sense of chirality. $\mathrm{An}_{2} \mathrm{H}_{2}$ generation system based on glucose and glucose oxidase allows for an accurate fine tuning of the aerobic protocol in order to adapt to the efficacy of the heme enzyme on different furan derivatives providing full conversions and high yields even for very slowly reacting substrates.

\section{Experimental Section}

Commercially available reagents were used without further purification. Furfuryl alcohols and furyl carbamates were synthesized as previously described. ${ }^{[11,24]}$ Catalysts and cofactors were obtained from: NADH, Carbolution Chemicals $\mathrm{GmbH}$; lactoperoxidase from Bos taurus (LPO, $106 \mathrm{U} / \mathrm{mg}$, Bio-Research Products Inc.), peroxidase from Armoracia rusticana (HRP, 148 $\mathrm{U} / \mathrm{mg}$, Sigma); peroxidase from Glycine $\max (\mathrm{SBP}, 17.5 \mathrm{kU} / \mathrm{mL}$, Bio-Research Products Inc.); chloroperoxidase from Caldariomyces fumago (CPO, $10.0 \mathrm{kU} / \mathrm{mL}$, Sigma), glucose oxidase type II from Aspergillus niger (GOx, $19.3 \mathrm{U} / \mathrm{mg}$, Sigma); L-Amino acid oxidase from Crotalus atrox $(0.1 \mathrm{U} / \mathrm{mg}$, Sigma); alcohol dehydrogenase recombinant from Escherichia coli (ADH 200, $17.6 \mathrm{U} / \mathrm{mg}$ evocatal $\mathrm{GmbH}$ ); alcohol dehydrogenase, recombinant from Escherichia coli $(\mathrm{ADH} 030,18.8 \mathrm{U} / \mathrm{mg}$, evocatal $\mathrm{GmbH})$; glucose dehydrogenase, recombinant from Escherichia coli (GDH 060, $214 \mathrm{U} / \mathrm{mg}$, evocatal $\mathrm{GmbH}$ ); Lipase from Candida sp., recombinant from Aspergillus niger, non-immobilized (7.3 $\mathrm{kU} / \mathrm{mL}$, Sigma); immobilized recombinant Lipase B from Candida antarctica, (14.3 kU/g, c-LEcta $\mathrm{GmbH})$; catalase from Corynebacterium glutamicum $(500 \mathrm{kU} / \mathrm{mL}$, Sigma). Enzymatic reactions were performed under non-inert conditions on an orbital shaker in open glass vials or round bottom flasks. Column chromatography was performed with silica gel from Merck (Millipore 60, 40-60 $\mu \mathrm{m}, \quad 240-400$ mesh). Reactions were monitored by thin layer chromatography (TLC) carried out on Macherey-Nagel pre-coated silica gel plates (TLC Silica gel 60 $F_{254}$ ). Visualisation of the TLC plates was done by using UV light or staining with a basic potassium permanganate solution. ${ }^{1} \mathrm{H}$ and ${ }^{13} \mathrm{C}$ NMR spectra were recorded on Bruker instruments (Avance 300 or Avance 400 ) at $20^{\circ} \mathrm{C}$. Chemical shifts are reported in parts per million (ppm) calibrated using residual non-deuterated solvent as internal reference $\left(\mathrm{CHCl}_{3}\right.$ at $\delta=7.26 \mathrm{ppm}\left({ }^{1} \mathrm{H} \mathrm{NMR}\right)$ and $\delta=77.16$ ppm $\left.\left({ }^{13} \mathrm{C} \mathrm{NMR}\right)\right)$. Infrared spectra were recorded on a Bruker ALPHA Eco-ATR spectrometer, absorption bands are reported in wave numbers $\left[\mathrm{cm}^{-1}\right]$. High resolution mass spectrometry was performed on an Agilent 6530 (Q-TOF) mass spectrometer. Optical rotations were measured on an Autopol VI polarimeter from Rudolph Research Analytical. Uncorrected melting points were measured on a Stuart SMP30 melting point apparatus using open glass capillaries. Gas chromatography analysis was performed on a Hewlett Packard HP 6890 Series
GC System using a Macherey-Nagel FS-Lipodex E column (25 m x $0.25 \mathrm{~mm}), \mathrm{N}_{2}, 1.0 \mathrm{ml} / \mathrm{min}: 50^{\circ} \mathrm{C}(1 \mathrm{~min}) / 5^{\circ} \mathrm{C} \cdot \mathrm{min}^{-1}(35 \mathrm{~min}) /$ $120{ }^{\circ} \mathrm{C}(15 \mathrm{~min})$.

General procedure for the chloroperoxidase-mediated oxidative ring expansion: In a $100 \mathrm{~mL}$ round bottom flask, the furylcarbinol (10 mM, $0.5 \mathrm{mmol})$ was dissolved in a mixture of citrate buffer ( $45 \mathrm{~mL}, 100 \mathrm{mM}, \mathrm{pH} 5.5)$ and tert-butanol $(5 \mathrm{~mL})$. After addition of chloroperoxidase (500 U), glucose oxidase (500 $\mathrm{U})$ and D-glucose $(50 \mathrm{mM})$, the solution was incubated at $30{ }^{\circ} \mathrm{C}$ (200 rpm) for $120-180 \mathrm{~min}$. L-Methionine (250 mg) was added and the reaction mixture was extracted with ethyl acetate $(3 \times 15$ $\mathrm{mL}$ ). The combined organic layers were dried over $\mathrm{MgSO}_{4}$, evaporated under reduced pressure and the pyranone was obtained after column chromatographic purification $\left(\mathrm{SiO}_{2}\right.$, hexanes/ethyl acetate) as mixture of inseparable diastereomers.

6-Hydroxy-2-methyl-2H-pyran-3(6H)-one (2a): Colorless solid (53.4 mg, $0.417 \mathrm{mmol}, 83 \%$ yield; $\alpha / \beta=67 / 33$ ). $[\alpha]^{20} \mathrm{D}:-79.6$ (c $\left.0.50, \mathrm{CHCl}_{3}\right), 99 \%$ ee, if starting from $(R)-1$ a. M.p.: $61^{\circ} \mathrm{C} . \mathrm{R}_{f}$ (cyclohexane/ethyl acetate, 2/1): 0.25. Major isomer: ${ }^{1} \mathrm{H}$ NMR $\left(300 \mathrm{MHz}, \mathrm{CDCl}_{3}\right): \delta[\mathrm{ppm}]=6.89\left(\mathrm{dd},{ }^{3} \mathrm{~J}=10.2 \mathrm{~Hz},{ }^{3} \mathrm{~J}=3.2 \mathrm{~Hz}\right.$, $1 \mathrm{H}), 6.10\left(\mathrm{~d},{ }^{3} \mathrm{~J}=10.2 \mathrm{~Hz}, 1 \mathrm{H}\right), 5.63(\mathrm{~m}, 1 \mathrm{H}), 4.71\left(\mathrm{q},{ }^{3} \mathrm{~J}=6.7 \mathrm{~Hz}\right.$, $1 \mathrm{H}), 3.53\left(\mathrm{~d},{ }^{3} \mathrm{~J}=5.0 \mathrm{~Hz}, 1 \mathrm{H}\right), 1.38\left(\mathrm{~d},{ }^{3} \mathrm{~J}=6.7 \mathrm{~Hz}, 3 \mathrm{H}\right) ;{ }^{13} \mathrm{C}$ NMR $\left(75 \mathrm{MHz}, \mathrm{CDCl}_{3}\right): \delta$ [ppm] = 197.0, 144.5, 127.3, 87.7, 70.4, 15.3. Minor isomer: ${ }^{1} \mathrm{H}$ NMR $\left(300 \mathrm{MHz}, \mathrm{CDCl}_{3}\right): \delta[\mathrm{ppm}]=6.94\left(\mathrm{~d},{ }^{3} \mathrm{~J}=\right.$ $10.2 \mathrm{~Hz}, 1 \mathrm{H}), 6.15\left(\mathrm{~d},{ }^{3} \mathrm{~J}=10.2 \mathrm{~Hz}, 1 \mathrm{H}\right), 5.67\left(\mathrm{~d},{ }^{3} \mathrm{~J}=7.2 \mathrm{~Hz}, 1 \mathrm{H}\right)$, $4.23(1 \mathrm{H}, \mathrm{m}), 3.87\left(\mathrm{~d},{ }^{3} \mathrm{~J}=7.2 \mathrm{~Hz}, 1 \mathrm{H}\right), 1.45\left(\mathrm{~d},{ }^{3} \mathrm{~J}=6.7 \mathrm{~Hz}, 3 \mathrm{H}\right)$; ${ }^{13} \mathrm{C} \mathrm{NMR}\left(75 \mathrm{MHz}, \mathrm{CDCl}_{3}\right): \delta[\mathrm{ppm}]=196.5,148.1,128.6,91.0$, 75.3, 16.2. FT-IR (neat, ATR): $v$ [cm $\left.{ }^{-1}\right]=3294(\mathrm{br}), 3051(\mathrm{w}), 2987$ (w), $1676(\mathrm{~s}), 1435(\mathrm{~m}), 1371(\mathrm{~m}), 1334(\mathrm{w}), 1273(\mathrm{w}), 1232(\mathrm{~m})$, $1143(\mathrm{~m}), 1109(\mathrm{~m}), 1091(\mathrm{~m}), 1031(\mathrm{~s}), 937(\mathrm{~m}), 900(\mathrm{~m}), 808$ $(\mathrm{m}), 690(\mathrm{~m})$. GC: $\alpha-(2 R)-\mathbf{2} \mathbf{a}=37.0 \mathrm{~min}, \alpha-(2 S)-2 \mathbf{a}=37.6 \mathrm{~min}$. This reaction was also successfully scaled up to a preparative level: 1a (5.61 g, $50 \mathrm{mmol})$, D-glucose (10.8 g, $60 \mathrm{mmol})$, glucose oxidase $(5 \mathrm{kU})$, chloroperoxidase $(10 \mathrm{kU})$ in citrate buffer $(900 \mathrm{~mL}$, $100 \mathrm{mM}, \mathrm{pH} 5.5)$ and tert-butanol $(100 \mathrm{~mL}), 30^{\circ} \mathrm{C}, 5 \mathrm{~h}$, to yield $2 \mathrm{a}$ $(4.91 \mathrm{~g}(38.2 \mathrm{mmol})$ after chromatographic purification.

6-Hydroxy-2-ethyl-2H-pyran-3(6H)-one (2b): Colorless oil (54.9 mg, $386 \mu \mathrm{mol}, 77 \%$ yield; $\alpha / \beta=68 / 32$ ). $[\alpha]^{20} \mathrm{D}:-24.9$ (c 0.55, $\mathrm{CHCl}_{3}$ ), $99 \%$ ee, if starting from $(R)-\mathbf{1 b}$. $\mathrm{R}_{f}$ (cyclohexane/ethyl acetate, 2/1): 0.27. Major isomer: ${ }^{1} \mathrm{H}$ NMR $\left(300 \mathrm{MHz}, \mathrm{CDCl}_{3}\right): \delta$ [ppm] = 6.97-6.89 (dd, $\left.{ }^{3} \mathrm{~J}=10.4 \mathrm{~Hz},{ }^{3} \mathrm{~J}=3.4 \mathrm{~Hz}, 1 \mathrm{H}\right), 6.18-6.10$ $\left(\mathrm{d},{ }^{3} \mathrm{~J}=10.3 \mathrm{~Hz}, 1 \mathrm{H}\right), 5.68(\mathrm{~m}, 1 \mathrm{H}), 4.53\left(\mathrm{dd},{ }^{3} \mathrm{~J}=7.4 \mathrm{~Hz},{ }^{3} \mathrm{~J}=4.1\right.$ $\mathrm{Hz}, 1 \mathrm{H}), 3.37$ (s, $1 \mathrm{H}), 2.06-1.71(\mathrm{~m}, 2 \mathrm{H}), 1.06-0.97(\mathrm{~m}, 3 \mathrm{H}) ;{ }^{13} \mathrm{C}$ $\operatorname{NMR}\left(75 \mathrm{MHz}, \mathrm{CDCl}_{3}\right): \delta[\mathrm{ppm}]=196.2,144.4,127.7,87.7,75.2$, 23.0, 23.0, 9.32. Minor isomer (selected signals): ${ }^{1} \mathrm{H}$ NMR (300 $\left.\mathrm{MHz} \mathrm{CDCl}_{3}\right): \delta[\mathrm{ppm}]=4.06-4.02(\mathrm{~m}, 1 \mathrm{H}), 3.65\left(\mathrm{dd},{ }^{3} \mathrm{~J}=7.3 \mathrm{~Hz}\right.$, $\left.{ }^{3} J=4.1 \mathrm{~Hz}, 1 \mathrm{H}\right) ;{ }^{13} \mathrm{C} \mathrm{NMR}\left(75 \mathrm{MHz}, \mathrm{CDCl}_{3}\right): \delta[\mathrm{ppm}]=147.8$, 128.8, 90.9, 80.0, 23.9, 9.6. FT-IR (neat, ATR): $v\left[\mathrm{~cm}^{-1}\right]=3307$ (br), $2978(\mathrm{w}), 1666(\mathrm{~s}), 1458(\mathrm{w}), 1377(\mathrm{~m}), 1267(\mathrm{~m}), 1234(\mathrm{~m})$, $1161(\mathrm{~m}), 1112(\mathrm{~m}), 1080(\mathrm{~m}), 1026(\mathrm{~s}), 960(\mathrm{~m}), 889(\mathrm{w}), 777(\mathrm{~m})$, $750(\mathrm{~m}), 692(\mathrm{~m})$. 
6-Hydroxy-2-propyl-2H-pyran-3(6H)-one (2c): Colorless oil (41.4 mg, $265 \mu \mathrm{mol}, 53 \%$ yield; $\alpha / \beta=65 / 35$ ). $[\alpha]^{20} \mathrm{D}:-17.9$ (c 0.52 , $\mathrm{CHCl}_{3}$ ), $98 \%$ ee, if starting from $(R)-\mathbf{1 c} . \mathrm{R}_{f}$ (cyclohexane/ethyl acetate, 2/1): 0.29. Major isomer: ${ }^{1} \mathrm{H}$ NMR $\left(300 \mathrm{MHz} \mathrm{CDCl}_{3}\right): \delta$ [ppm] $=6.92\left(\mathrm{dd},{ }^{3} \mathrm{~J}=10.1 \mathrm{~Hz},{ }^{3} \mathrm{~J}=3.2 \mathrm{~Hz}, 1 \mathrm{H}\right), 6.15\left(\mathrm{~d},{ }^{3} \mathrm{~J}=10.2\right.$ $\mathrm{Hz}, 1 \mathrm{H}), 5.68-5.64(\mathrm{~m}, 1 \mathrm{H}), 4.58\left(\mathrm{dd},{ }^{3} \mathrm{~J}=8.1 \mathrm{~Hz},{ }^{3} \mathrm{~J}=3.9 \mathrm{~Hz}, 1 \mathrm{H}\right)$, 3.17 (br s, $1 \mathrm{H}), 2.10-1.39(\mathrm{~m}, 4 \mathrm{H}), 0.96\left(\mathrm{t},{ }^{3} \mathrm{~J}=7.4 \mathrm{~Hz}, 3 \mathrm{H}\right) ;{ }^{13} \mathrm{C}$ $\operatorname{NMR}\left(75 \mathrm{MHz}, \mathrm{CDCl}_{3}\right): \delta[\mathrm{ppm}]=194.8,144.3,127.6,87.6,74.0$, $31.6,18.2,13.8$. Minor isomer (selected signals): ${ }^{1} \mathrm{H}$ NMR (300 $\left.\mathrm{MHz}, \mathrm{CDCl}_{3}\right): \delta[\mathrm{ppm}]=4.10\left(\mathrm{dd},{ }^{3} \mathrm{~J}=8.2 \mathrm{~Hz},{ }^{3} \mathrm{~J}=4.1 \mathrm{~Hz}, 1 \mathrm{H}\right)$, $0.92\left(\mathrm{t},{ }^{3} \mathrm{~J}=7.4 \mathrm{~Hz}, 3 \mathrm{H}\right) ;{ }^{13} \mathrm{C}$ NMR $\left(75 \mathrm{MHz}, \mathrm{CDCl}_{3}\right): \delta[\mathrm{ppm}]=$ 147.7, 128.8, 91.1, 78.7, 32.6, 18.2, 13.8. FT-IR (neat, ATR): $v$ $\left[\mathrm{cm}^{-1}\right]=3394(\mathrm{br}), 2960(\mathrm{~m}), 2873(\mathrm{w}), 1685(\mathrm{~s}), 1458(\mathrm{~m}), 1375$ (m), $1265(\mathrm{~m}), 1215(\mathrm{w}), 1157(\mathrm{w}), 1083(\mathrm{~m}), 1020(\mathrm{~s}), 914(\mathrm{w})$, 759 (w). GC: $\alpha-(2 R)-2 c=41.0 \mathrm{~min}, \alpha-(2 S)-2 \mathrm{c}=41.9 \mathrm{~min}$.

6-Hydroxy-2-allyl-2H-pyran-3(6H)-one (2e): Colorless oil (50.1 mg, $325 \mu \mathrm{mol}, 65 \%$ yield; $\alpha / \beta=69 / 31)$. $[\alpha]^{20} \mathrm{D}:-33.6$ (c 0.59 , $\mathrm{CHCl}_{3}$ ), 98\% ee, if starting from $(R)-1 e . \mathrm{R}_{f}$ (cyclohexane/ethyl acetate, 2/1): 0.27. Major isomer: ${ }^{1} \mathrm{H}$ NMR $\left(300 \mathrm{MHz}, \mathrm{CDCl}_{3}\right): \delta$ [ppm] $=6.90\left(\mathrm{dd},{ }^{3} \mathrm{~J}=10.3 \mathrm{~Hz},{ }^{3} \mathrm{~J}=3.7 \mathrm{~Hz}, 1 \mathrm{H}\right), 6.11\left(\mathrm{~d},{ }^{3} \mathrm{~J}=10.3\right.$ $\mathrm{Hz}, 1 \mathrm{H}), 5.89-5.78(\mathrm{~m}, 1 \mathrm{H}), 5.66(\mathrm{~m}, 1 \mathrm{H}), 5.18-5.09(\mathrm{~m}, 2 \mathrm{H}), 4.67$ $\left(\mathrm{dd},{ }^{3} \mathrm{~J}=8.0 \mathrm{~Hz},{ }^{3} \mathrm{~J}=3.8 \mathrm{~Hz}, 1 \mathrm{H}\right), 2.73-2.71(\mathrm{~m}, 1 \mathrm{H}), 2.58-2.46$ $(\mathrm{m}, 1 \mathrm{H}) ;{ }^{13} \mathrm{C} \mathrm{NMR}\left(75 \mathrm{MHz}, \mathrm{CDCl}_{3}\right): \delta[\mathrm{ppm}]=195.9,144.5,133.7$, 127.6, 118.1, 87.7, 73.7, 34.1. Minor isomer (selected signals): ${ }^{1} \mathrm{H}$ $\operatorname{NMR}\left(300 \mathrm{MHz}, \mathrm{CDCl}_{3}\right): \delta[\mathrm{ppm}]=6.94\left(\mathrm{dd},{ }^{3} \mathrm{~J}=10.2 \mathrm{~Hz},{ }^{3} \mathrm{~J}=1.6\right.$ $\mathrm{Hz}, 1 \mathrm{H}), 6.16\left(\mathrm{~d},{ }^{3} \mathrm{~J}=10.2 \mathrm{~Hz}, 1 \mathrm{H}\right), 4.18-4.16\left(\mathrm{dd},{ }^{3} \mathrm{~J}=8.2 \mathrm{~Hz},{ }^{3} \mathrm{~J}\right.$ $=3.9 \mathrm{~Hz}, 1 \mathrm{H}) ;{ }^{13} \mathrm{C} \operatorname{NMR}\left(75 \mathrm{MHz}, \mathrm{CDCl}_{3}\right): \delta=195.8,147.9,133.6$, 128.6, 117.8, 90.8, 78.5, 35.1. FT-IR (neat, ATR): $v\left[\mathrm{~cm}^{-1}\right]=3381$ (br), $2958(w), 1685(\mathrm{~s}), 1431(w), 1373(w), 1267(w), 1211(w)$, 1155 (w), 1087 (m), 1022 (s), 918 (m), 800 (w), 765 (w). GC: $\alpha-$ $(2 R)-2 \mathbf{e}=41.9 \mathrm{~min}, \alpha-(2 S)-2 \mathbf{e}=43.1 \mathrm{~min}$.

6-Hydroxy-2-tert-butyl-2H-pyran-3(6H)-one (2h): Colorless oil (6.8 mg, $40 \mu \mathrm{mol}, 4 \%$ yield; $\alpha / \beta=70 / 30$ ). $\mathrm{R}_{f}$ (cyclohexane/ethyl acetate, 2/1): 0.35 . Major isomer: ${ }^{1} \mathrm{H}$ NMR $\left(300 \mathrm{MHz}, \mathrm{CDCl}_{3}\right): \delta$ [ppm] $=6.84\left(\mathrm{dd},{ }^{3} \mathrm{~J}=10.2 \mathrm{~Hz},{ }^{3} \mathrm{~J}=3.2 \mathrm{~Hz}, 1 \mathrm{H}\right), 6.04\left(\mathrm{~d},{ }^{3} \mathrm{~J}=10.2\right.$ $\mathrm{Hz}, 1 \mathrm{H}), 5.66\left(\mathrm{~d},{ }^{3} \mathrm{~J}=3.2 \mathrm{~Hz}, 1 \mathrm{H}\right), 4.21(\mathrm{~s}, 1 \mathrm{H}), 3.48(\mathrm{br} \mathrm{s}, 1 \mathrm{H})$, 1.06 (s, 9H); ${ }^{13} \mathrm{C}-\mathrm{NMR}\left(75 \mathrm{MHz}, \mathrm{CDCl}_{3}\right): \delta[\mathrm{ppm}]=196.8,143.4$, 128.8, 87.9, 80.2, 34.9, 26.3. Minor isomer (selected signals): ${ }^{1} \mathrm{H}$ $\operatorname{NMR}\left(300 \mathrm{MHz}, \mathrm{CDCl}_{3}\right): \delta[\mathrm{ppm}]=6.89-6.85(\mathrm{~m}, 1 \mathrm{H}), 6.10-6.06$ $(\mathrm{m}, 1 \mathrm{H}), 5.60(\mathrm{~m}, 1 \mathrm{H}), 3.70(\mathrm{~s}, 1 \mathrm{H}), 3.69\left(\mathrm{~d},{ }^{3} \mathrm{~J}=1.2 \mathrm{~Hz}, 1 \mathrm{H}\right), 1.09$ $(\mathrm{s}, 9 \mathrm{H}) ;{ }^{13} \mathrm{C}-\mathrm{NMR}\left(75 \mathrm{MHz}, \mathrm{CDCl}_{3}\right): \delta[\mathrm{ppm}]=196.1,147.1,130.4$, 91.8, 85.1. FT-IR (neat, ATR): $v\left[\mathrm{~cm}^{-1}\right]=3371(\mathrm{br}), 2958(\mathrm{~m})$, $2872(w), 1726(m), 1681(s), 1633(w), 1463(w), 1363(m), 1300$ (m), $1234(\mathrm{~m}), 1182(\mathrm{~m}), 1089(\mathrm{~m}), 1026(\mathrm{~s}), 1004(\mathrm{~s}), 968(\mathrm{~m})$, $900(\mathrm{~m}), 821(\mathrm{w}), 746(\mathrm{~m})$.

6-Hydroxy-2-phenyl-2H-pyran-3(6H)-one (2i): Colorless oil (25.2 mg, $132 \mu \mathrm{mol}, 26 \%$ yield; $\alpha / \beta=75 / 25) . \quad \mathrm{R}_{f}$ (cyclohexane/ethyl acetate, 2/1): 0.30 . Major isomer: ${ }^{1} \mathrm{H}$ NMR $\left(300 \mathrm{MHz}, \mathrm{CDCl}_{3}\right): \delta[\mathrm{ppm}]=7.41-7.33(\mathrm{~m}, 5 \mathrm{H}), 6.95\left(\mathrm{dd},{ }^{3} \mathrm{~J}=\right.$ $\left.10.2 \mathrm{~Hz},{ }^{3} \mathrm{~J}=3.3 \mathrm{~Hz}, 1 \mathrm{H}\right), 6.21\left(\mathrm{~d},{ }^{3} \mathrm{~J}=10.3 \mathrm{~Hz}, 1 \mathrm{H}\right), 5.73-5.71$ $(\mathrm{m}, 1 \mathrm{H}), 5.59(\mathrm{~s}, 1 \mathrm{H}), 3.44\left(\mathrm{~d},{ }^{3} \mathrm{~J}=5.1 \mathrm{~Hz}, 1 \mathrm{H}\right) ;{ }^{13} \mathrm{C} \mathrm{NMR}(75 \mathrm{MHz}$, $\left.\mathrm{CDCl}_{3}\right): \delta[\mathrm{ppm}]=194.5,144.8,135.2,128.6,128.5,128.0,127.9$, 88.0, 77.0. Minor isomer: ${ }^{1} \mathrm{H} \mathrm{NMR}\left(300 \mathrm{MHz}, \mathrm{CDCl}_{3}\right): \delta[\mathrm{ppm}]=$ 7.41-7.33 (m, 5H), 7.01-6.97 (m, 1H), $6.26\left(\mathrm{dd},{ }^{3} \mathrm{~J}=10.3 \mathrm{~Hz},{ }^{4} \mathrm{~J}=\right.$ $1.6 \mathrm{~Hz}, 1 \mathrm{H}), 5.79-5.76(\mathrm{~m}, 1 \mathrm{H}), 5.09\left(\mathrm{~d},{ }^{3} \mathrm{~J}=1.5 \mathrm{~Hz}, 1 \mathrm{H}\right), 3.64(\mathrm{~d}$, $\left.{ }^{3} J=7.2 \mathrm{~Hz}, 1 \mathrm{H}\right) ;{ }^{13} \mathrm{C}$ NMR $\left(75 \mathrm{MHz}, \mathrm{CDCl}_{3}\right): \delta[\mathrm{ppm}]=194.1$, 148.2, 128.3, 91.5, 81.1. FT-IR (neat, ATR): $v\left[\mathrm{~cm}^{-1}\right]=3392(\mathrm{br})$, $1689(\mathrm{~s}), 1629(\mathrm{w}), 1469(\mathrm{w}), 1454(\mathrm{~m}), 1371(\mathrm{w}), 1290(\mathrm{~m}), 1219$ (m), $1089(\mathrm{~m}), 1074(\mathrm{~m}), 1024(\mathrm{~s}), 1002(\mathrm{~s}), 945(\mathrm{~m}), 891(\mathrm{~m}), 794$ (w), 750 (s), 698 (s).

\section{6-Hydroxy-2-ethoxycarbonylmethyl-2 $\mathrm{H}$-pyran-3(6H)-one (2j):} Colorless oil (68.1 mg, $340 \mu \mathrm{mol}, 68 \%$ yield; $\alpha / \beta=72 / 28) .[\alpha]^{20} \mathrm{D}$ : +7.4 (c 1.00, $\mathrm{CHCl}_{3}$ ), 99\% ee, if starting from $(R)-\mathbf{1 j}$. $\mathrm{R}_{f}$ (cyclohexane/ethyl acetate, 2/1): 0.19. Major isomer: ${ }^{1} \mathrm{H}$ NMR $\left(300 \mathrm{MHz}, \mathrm{CDCl}_{3}\right): \delta[\mathrm{ppm}]=6.93\left(\mathrm{dd},{ }^{3} \mathrm{~J}=10.3 \mathrm{~Hz},{ }^{3} \mathrm{~J}=3.5 \mathrm{~Hz}\right.$, $1 \mathrm{H}), 6.17\left(\mathrm{~d},{ }^{3} \mathrm{~J}=10.3 \mathrm{~Hz}, 1 \mathrm{H}\right), 5.75-5.53(\mathrm{~m}, 1 \mathrm{H}), 5.03\left(\mathrm{dd},{ }^{3} \mathrm{~J}=\right.$ $\left.7.2 \mathrm{~Hz},{ }^{3} \mathrm{~J}=4.0 \mathrm{~Hz}, 1 \mathrm{H}\right), 3.00-2.98(\mathrm{~m}, 1 \mathrm{H}), 2.85-2.68(\mathrm{~m}, 1 \mathrm{H})$, 1.30-1.25 (m, 3H). ${ }^{13} \mathrm{C}$ NMR $\left(75 \mathrm{MHz}, \mathrm{CDCl}_{3}\right): \delta[\mathrm{ppm}]=195.0$, 171.0, 144.6, 127.1, 87.4, 70.7, 61.0, 35.3, 14.1. Minor isomer (selected signals): ${ }^{1} \mathrm{H} \mathrm{NMR}\left(300 \mathrm{MHz}, \mathrm{CDCl}_{3}\right): \delta[\mathrm{ppm}]=6.98$ (dd, $\left.{ }^{3} J=10.3 \mathrm{~Hz},{ }^{3} J=1.5 \mathrm{~Hz}, 1 \mathrm{H}\right), 6.13\left(\mathrm{dd},{ }^{3} J=10.3 \mathrm{~Hz},{ }^{3} J=1.5 \mathrm{~Hz}\right.$, $1 \mathrm{H}), 4.61-4.57(\mathrm{~m}, 1 \mathrm{H}), 4.21-4.13(\mathrm{~m}, 3 \mathrm{H}), 3.06-3.03(\mathrm{~m}, 1 \mathrm{H}) .{ }^{13} \mathrm{C}$ $\operatorname{NMR}\left(75 \mathrm{MHz}, \mathrm{CDCl}_{3}\right): \delta[\mathrm{ppm}]=194.4,171.0,148.4,128.4,90.9$, 75.3, 67.4, 36.2, 14.1. FT-IR (neat, ATR): $v\left[\mathrm{~cm}^{-1}\right]=3420(\mathrm{br})$, $2988(w), 1732(\mathrm{~m}), 1693(\mathrm{~m}), 1375(\mathrm{w}), 1286(\mathrm{w}), 1178(\mathrm{~m}), 1089$ (m9 1020 (s), 931 (w), $846(w), 759(w)$.

6-Hydroxy-2-chloromethyl-2H-pyran-3(6H)-one

(2k):

Colorless solid $(52.0 \mathrm{mg}, 320 \mu \mathrm{mol}, 64 \%$ yield; $\alpha / \beta=64 / 36)$. $[\alpha]^{20} \mathrm{D}:-2.8$ (c $\left.0.51, \mathrm{CHCl}_{3}\right), 99 \%$ ee, if starting from (S)-1k. M.p.: $75^{\circ} \mathrm{C}$. $\mathrm{R}_{f}$ (cyclohexane/ethyl acetate, $2 / 1$ ): 0.23 . Major isomer: ${ }^{1} \mathrm{H}$ $\operatorname{NMR}\left(300 \mathrm{MHz}, \mathrm{CDCl}_{3}\right): \delta[\mathrm{ppm}]=7.00\left(\mathrm{dd},{ }^{3} \mathrm{~J}=10.3 \mathrm{~Hz},{ }^{3} \mathrm{~J}=3.6\right.$ $\mathrm{Hz}, 1 \mathrm{H}), 6.19\left(\mathrm{~d},{ }^{3} \mathrm{~J}=10.3 \mathrm{~Hz}, 1 \mathrm{H}\right), 5.79(\mathrm{~m}, 1 \mathrm{H}), 4.90$ (dd, ${ }^{3} \mathrm{~J}=$ $\left.5.5 \mathrm{~Hz},{ }^{3} \mathrm{~J}=3.2 \mathrm{~Hz}, 1 \mathrm{H}\right), 3.98-3.92(\mathrm{~m}, 2 \mathrm{H}), 3.62-3.58(\mathrm{~m}, 1 \mathrm{H})$. ${ }^{13} \mathrm{C} \mathrm{NMR}\left(75 \mathrm{MHz}, \mathrm{CDCl}_{3}\right): \delta[\mathrm{ppm}]=193.0,145.1,127.5,87.9$, 74.0, 42.9. Minor isomer (selected signals): ${ }^{1} \mathrm{H}$ NMR $(300 \mathrm{MHz}$, $\left.\left.\mathrm{CDCl}_{3}\right): \delta \mathrm{ppm}\right]=7.03\left(\mathrm{dd},{ }^{3} \mathrm{~J}=10.3 \mathrm{~Hz},{ }^{3} \mathrm{~J}=1.6 \mathrm{~Hz}, 1 \mathrm{H}\right), 6.23$ (dd, $\left.{ }^{3} J=1.5 \mathrm{~Hz},{ }^{3} \mathrm{~J}=10.3 \mathrm{~Hz}, 1 \mathrm{H}\right), 4.43$ (dd, ${ }^{3} \mathrm{~J}=6.3 \mathrm{~Hz},{ }^{3} \mathrm{~J}=3.8$ $\mathrm{Hz}, 1 \mathrm{H}), 4.01-3.99(\mathrm{~m}, 1 \mathrm{H}) .{ }^{13} \mathrm{C} \mathrm{NMR}\left(75 \mathrm{MHz}, \mathrm{CDCl}_{3}\right): \delta[\mathrm{ppm}]=$ 192.6, 148.2, 128.4, 90.4, 78.5, 43.7. FT-IR (neat, ATR): $v$ [cm-1] $=3329(\mathrm{br}), 1666(\mathrm{~s}), 1631(\mathrm{w}), 1436(\mathrm{w}), 1371(\mathrm{w}), 1273(\mathrm{~m})$, $1232(\mathrm{~m}), 1192(\mathrm{w}), 1153(\mathrm{w}), 1107(\mathrm{~m}), 1080(\mathrm{~m}), 1028(\mathrm{~s}), 902$ (m), $802(\mathrm{~m}), 763(\mathrm{~m}), 731(\mathrm{~m}), 690(\mathrm{~m})$.

6-Hydroxy-2-hydroxymethyl-2H-pyran-3(6H)-one (2l): Yellow oil $(22.3 \mathrm{mg}, 155 \mu \mathrm{mol}, 31 \%$ yield; $\alpha / \beta=55 / 44)$. $[\alpha]^{20} \mathrm{D}:+22.5$ (c $0.55, \mathrm{CHCl}_{3}$ ), $99 \%$ ee, if starting from $(R)-1 \mathrm{l}$. $\mathrm{R}_{f}$ (cyclohexane/ethyl acetate, 1/1): 0.15 . Major isomer: ${ }^{1} \mathrm{H}$ NMR $\left(300 \mathrm{MHz}, \mathrm{CDCl}_{3}\right): \delta$ [ppm] = 6.98-6.93 (m, 1H), $6.15\left(\mathrm{~d},{ }^{3} \mathrm{~J}=10.3 \mathrm{~Hz}, 1 \mathrm{H}\right), 5.72\left(\mathrm{~d},{ }^{3} \mathrm{~J}\right.$ $=3.4 \mathrm{~Hz}, 1 \mathrm{H}), 4.67\left(\mathrm{t},{ }^{3} \mathrm{~J}=4.5 \mathrm{~Hz}, 1 \mathrm{H}\right), 4.10-3.88(\mathrm{~m}, 2 \mathrm{H}) ;{ }^{13} \mathrm{C}$ $\operatorname{NMR}\left(75 \mathrm{MHz}, \mathrm{CDCl}_{3}\right): \delta=145.0,127.8,87.5,74.1,61.8$. Minor isomer (selected signals): ${ }^{1} \mathrm{H} \mathrm{NMR}\left(300 \mathrm{MHz}, \mathrm{CDCl}_{3}\right): \delta$ [ppm] = 
$6.22\left(\mathrm{~d},{ }^{3} \mathrm{~J}=10.4 \mathrm{~Hz}, 1 \mathrm{H}\right), 5.65\left(\mathrm{~d},{ }^{3} \mathrm{~J}=1.8 \mathrm{~Hz}, 1 \mathrm{H}\right), 4.53\left(\mathrm{t},{ }^{3} \mathrm{~J}=\right.$ $3.5 \mathrm{~Hz}, 1 \mathrm{H}) ;{ }^{13} \mathrm{C}$ NMR $\left(75 \mathrm{MHz}, \mathrm{CDCl}_{3}\right): \delta=146.9,128.5$. FT-IR (neat, ATR): $v$ [cm $\left.{ }^{-1}\right]=3392(\mathrm{br}), 2942(\mathrm{~m}), 2854(\mathrm{w}), 2358(\mathrm{~s})$, $2331(\mathrm{~m}), 1683(\mathrm{~m}), 1465$ (m), 1375 (w) 1103 (w), $1029(\mathrm{~m}), 769$ (w), $669(\mathrm{~m})$.

6-Hydroxy-2-butyl-2H-pyran-3(6H)-one (2o): Colorless oil (31.5 $\mathrm{mg}, 185 \mu \mathrm{mol}, 37 \%$ yield; $\alpha / \beta=76 / 24)$. $\mathrm{R}_{f}$ (cyclohexane/ethyl acetate, 2/1): 0.33. Major isomer: ${ }^{1} \mathrm{H}$ NMR $\left(300 \mathrm{MHz}, \mathrm{CDCl}_{3}\right): \delta$ [ppm] $=6.80\left(\mathrm{dd},{ }^{3} \mathrm{~J}=10.1 \mathrm{~Hz},{ }^{3} \mathrm{~J}=3.3 \mathrm{~Hz}, 1 \mathrm{H}\right), 6.11\left(\mathrm{~d},{ }^{3} \mathrm{~J}=10.4\right.$ $\mathrm{Hz}, 1 \mathrm{H}), 5.66\left(\mathrm{~d},{ }^{3} \mathrm{~J}=3.1 \mathrm{~Hz}, 1 \mathrm{H}\right), 4.56(\mathrm{q}, 3 \mathrm{~J} 5,6=4.1 \mathrm{~Hz}, 1 \mathrm{H}, \mathrm{H}-$ 5), 3.00 (br s, $1 \mathrm{H}, \mathrm{OH}), 1.98-1.64(\mathrm{~m}, 2 \mathrm{H}, \mathrm{H}-6), 1.48-1.30(\mathrm{~m}, 4 \mathrm{H}$, $\mathrm{H}-7, \mathrm{H}-8), 0.91$ (t, $\left.{ }^{3} \mathrm{~J}=7.1 \mathrm{~Hz}, 3 \mathrm{H}, \mathrm{H}-9\right) ;{ }^{13} \mathrm{C} \mathrm{NMR}(75 \mathrm{MHz}$, $\left.\mathrm{CDCl}_{3}\right): \delta[\mathrm{ppm}]=196.8(\mathrm{C}-4), 144.1(\mathrm{C}-3), 127.7(\mathrm{C}-2), 87.7(\mathrm{C}-$ 1), 74.2 (C-5), 29.1 (C-6), 26.9, 22.2 (C-7, C- 8), 13.9 (C-9). Minor isomer (selected signals): ${ }^{1} \mathrm{H}$ NMR $\left(300 \mathrm{MHz}, \mathrm{CDCl}_{3}\right): \delta[\mathrm{ppm}]=$ 6.94-6.90 (m, 1H), 6.16- $6.12(\mathrm{~m}, 1 \mathrm{H}), 5.66\left(\mathrm{~d},{ }^{3} \mathrm{~J}=3.1 \mathrm{~Hz}, 1 \mathrm{H}\right)$, 4.09-4.05 (m, 1H), $3.24(\mathrm{br} \mathrm{s}, 1 \mathrm{H}), 1.98-1.64(\mathrm{~m}, 2 \mathrm{H}), 1.48-1.30$ $(\mathrm{m}, 4 \mathrm{H}), 0.91\left(\mathrm{t},{ }^{3} \mathrm{~J}=7.1 \mathrm{~Hz}, 3 \mathrm{H}\right) ;{ }^{13} \mathrm{C}$ NMR $\left(75 \mathrm{MHz}, \mathrm{CDCl}_{3}\right): \delta$ [ppm] $=147.5,128.8,90.9,79.0,30.4$. FT-IR (neat, ATR): $v\left[\mathrm{~cm}^{-1}\right]$ = $3327(\mathrm{br}), 2949(\mathrm{~m}), 2927(\mathrm{w}), 1672(\mathrm{~s}), 1627(\mathrm{w}), 1467(\mathrm{~m})$, $1373(\mathrm{~m}), 1309(\mathrm{w}), 1257(\mathrm{~m}), 1157(\mathrm{~m}), 1187(\mathrm{w}), 1087(\mathrm{~s}), 1026$ (s), $974(\mathrm{~m}), 933(\mathrm{w}), 875(\mathrm{~m}), 759(\mathrm{~m})$.

6-Hydroxy-2-pentyl-2H-pyran-3(6H)-one (2p): Colorless oil (5.7 $\mathrm{mg}, 31 \mu \mathrm{mol}, 6 \%$ yield; $\alpha / \beta=74 / 26) . \mathrm{R}_{f}$ (cyclohexane/ethyl acetate, 2/1): 0.34. Major isomer: ${ }^{1} \mathrm{H} \mathrm{NMR}\left(300 \mathrm{MHz}, \mathrm{CDCl}_{3}\right): \delta$ [ppm] $=6.88\left(\mathrm{dd},{ }^{3} \mathrm{~J}=10.2 \mathrm{~Hz},{ }^{3} \mathrm{~J}=3.3 \mathrm{~Hz}, 1 \mathrm{H}\right), 6.10\left(\mathrm{~d},{ }^{3} \mathrm{~J}=10.3\right.$ $\mathrm{Hz}, 1 \mathrm{H}), 5.65\left(\mathrm{~d},{ }^{3} \mathrm{~J}=3.0 \mathrm{~Hz}, 1 \mathrm{H}\right), 4.55\left(\mathrm{q},{ }^{3} \mathrm{~J}=3.9 \mathrm{~Hz}, 1 \mathrm{H}\right), 3.03$ (br s, $1 \mathrm{H}), 1.95-1.63(\mathrm{~m}, 2 \mathrm{H}), 1.33-1.20(\mathrm{~m}, 6 \mathrm{H}), 0.90-0.85(\mathrm{~m}$, $3 \mathrm{H}) ;{ }^{13} \mathrm{C} \mathrm{NMR}\left(75 \mathrm{MHz}, \mathrm{CDCl}_{3}\right): \delta[\mathrm{ppm}]=196.8,144.1,127.7$, 87.7, 74.3, 31.7, 29.6, 24.9, 22.6, 14.0. Minor isomer (selected signals): ${ }^{1} \mathrm{H} \mathrm{NMR}\left(300 \mathrm{MHz}, \mathrm{CDCl}_{3}\right): \delta[\mathrm{ppm}]=6.94-6.90(\mathrm{~m}, 1 \mathrm{H})$, 6.16- $6.12(\mathrm{~m}, 1 \mathrm{H}), 5.65\left(\mathrm{~d},{ }^{3} \mathrm{~J}=3.0 \mathrm{~Hz}, 1 \mathrm{H}\right), 4.09-4.05(\mathrm{~m}, 1 \mathrm{H})$, 3.26 (br s, $1 \mathrm{H}), 1.95-1.63(\mathrm{~m}, 2 \mathrm{H}), 1.33-1.20(\mathrm{~m}, 6 \mathrm{H}), 0.90-0.85$ $(\mathrm{m}, 3 \mathrm{H}) ;{ }^{13} \mathrm{C} \operatorname{NMR}\left(75 \mathrm{MHz}, \mathrm{CDCl}_{3}\right): \delta[\mathrm{ppm}]=147.5,128.8,90.9$, 79.2, 30.7, 29.1, 25.1, 22.8. FT-IR (neat, ATR): $v\left[\mathrm{~cm}^{-1}\right]=3317$ (br), $2949(\mathrm{~m}), 2873(\mathrm{~m}), 1674(\mathrm{~s}), 1627(\mathrm{w}), 1469(\mathrm{~m}), 1375(\mathrm{~m})$, $1274(\mathrm{~m}), 1242(\mathrm{~m}), 1157(\mathrm{~m}), 1093(\mathrm{~s}), 1026(\mathrm{~s}), 999(\mathrm{~m}), 952$ (m), $891(\mathrm{~m}), 785(\mathrm{~m}), 700(\mathrm{~m})$.

\footnotetext{
General procedure for the oxidase-limited modification of the biocatalytic Achmatowicz reaction: The furylcarbinol $(0.2 \mathrm{mmol})$ was dissolved in tert-Butanol $(2 \mathrm{~mL})$ and the solution was added to a mixture of chloroperoxidase (200 U), glucose oxidase $(6 \mathrm{U})$ in citrate buffer $(18 \mathrm{~mL}, 100 \mathrm{mM}, \mathrm{pH} 6.0)$. After addition of D-glucose $(50 \mathrm{mM})$, the reaction mixture was incubated at $30{ }^{\circ} \mathrm{C}(200 \mathrm{rpm})$ overnight. L-Methionine $(250 \mathrm{mg})$ was added and the reaction mixture was extracted with ethyl acetate $(3 \times 5$ $\mathrm{mL}$ ). The combined organic layers were dried over $\mathrm{MgSO}_{4}$, evaporated under reduced pressure and the pyranone was obtained after purification by column chromatography $\left(\mathrm{SiO}_{2}\right.$, hexanes/ethyl acetate).
}

6-Hydroxy-2-isopropyl-2H-pyran-3(6H)-one (2f): Colorless oil (26.9 mg, $172 \mu \mathrm{mol}, 86 \%$ yield; $\alpha / \beta=73 / 27$ ). $[\alpha]^{20} \mathrm{D}$ : -8.6 (c 0.50, $\mathrm{CHCl}_{3}$ ), 99\% ee, if starting from $(R)-\mathbf{1 f}$. $\mathrm{R}_{f}$ (cyclohexane/ethyl acetate, 2/1): 0.32. Major isomer: ${ }^{1} \mathrm{H}-\mathrm{NMR}\left(300 \mathrm{MHz}, \mathrm{CDCl}_{3}\right): \delta$ [ppm] $=6.93\left(\mathrm{dd},{ }^{3} \mathrm{~J}=10.2 \mathrm{~Hz},{ }^{3} \mathrm{~J}=3.4 \mathrm{~Hz}, 1 \mathrm{H}\right), 6.12\left(\mathrm{~d},{ }^{3} \mathrm{~J}=10.2\right.$ $\mathrm{Hz}, 1 \mathrm{H}), 5.71-5.65(\mathrm{~m}, 1 \mathrm{H}), 4.43\left(\mathrm{~d},{ }^{3} \mathrm{~J}=3.4 \mathrm{~Hz}, 1 \mathrm{H}\right), 3.15-3.10$ $(\mathrm{m}, 1 \mathrm{H}), 2.52-2.41(\mathrm{~m}, 1 \mathrm{H}), 1.05\left(\mathrm{~d},{ }^{3} \mathrm{~J}=7.1 \mathrm{~Hz}, 3 \mathrm{H}\right), 0.90\left(\mathrm{~d},{ }^{3} \mathrm{~J}=\right.$ $6.9 \mathrm{~Hz}, 3 \mathrm{H}) ;{ }^{13} \mathrm{C}-\mathrm{NMR}\left(75 \mathrm{MHz}, \mathrm{CDCl}_{3}\right): \delta[\mathrm{ppm}]=196.2,144.2$, 128.1, 87.7, 77.3, 28.6, 19.0, 16.2. Minor isomer (selected signals): ${ }^{1} \mathrm{H} \mathrm{NMR}\left(300 \mathrm{MHz}, \mathrm{CDCl}_{3}\right): \delta[\mathrm{ppm}]=6.14\left(\mathrm{dd},{ }^{3} J=10.3\right.$ $\left.\mathrm{Hz},{ }^{3} \mathrm{~J}=1.5 \mathrm{~Hz}, 1 \mathrm{H}\right), 3.93\left(\mathrm{dd},{ }^{3} \mathrm{~J}=3.4 \mathrm{~Hz},{ }^{3} \mathrm{~J}=1.3 \mathrm{~Hz}, 1 \mathrm{H}\right), 3.43-$ $3.37(\mathrm{~m}, 1 \mathrm{H}), 0.96\left(\mathrm{~d},{ }^{3} \mathrm{~J}=6.8 \mathrm{~Hz}, 3 \mathrm{H}\right) ;{ }^{13} \mathrm{C} \mathrm{NMR}\left(75 \mathrm{MHz}, \mathrm{CDCl}_{3}\right)$ : $\delta$ [ppm] $=148.0,129.5,91.2,83.1,28.9,19.1,16.5$. FT-IR (neat, ATR): $v\left[\mathrm{~cm}^{-1}\right]=3385(\mathrm{br}), 2966(\mathrm{w}), 1681(\mathrm{~m}), 1463(\mathrm{w}), 1369$ $(\mathrm{m}), 1273(\mathrm{w}), 1230(\mathrm{w}), 1153(\mathrm{w}), 1082(\mathrm{~m}), 1016(\mathrm{~s}), 946(\mathrm{~m})$, $885(\mathrm{w}), 756(\mathrm{~m}), 680(\mathrm{w})$. GC: $\alpha-(2 R)-\mathbf{2 f}=38.7 \mathrm{~min}, \alpha-(2 S)-\mathbf{2 f}=$ $39.9 \mathrm{~min}$.

6-Hydroxy-2-isobutyl-2H-pyran-3(6H)-one (2g): Colorless oil (30.3 mg, $178 \mu \mathrm{mol}, \quad 89 \%$ yield; $\alpha / \beta=70 / 30)$. $\mathrm{R}_{f}$ (cyclohexane/ethyl acetate, 2/1): 0.48 . Major isomer: ${ }^{1} \mathrm{H}$ NMR $\left(400 \mathrm{MHz}, \mathrm{CDCl}_{3}\right): \delta[\mathrm{ppm}]=6.90\left(\mathrm{dd},{ }^{3} \mathrm{~J}=10.2 \mathrm{~Hz},{ }^{3} \mathrm{~J}=3.4 \mathrm{~Hz}\right.$, $1 \mathrm{H}), 6.12\left(\mathrm{~d},{ }^{3} \mathrm{~J}=10.2 \mathrm{~Hz}, 1 \mathrm{H}\right), 5.66\left(\mathrm{~d},{ }^{3} \mathrm{~J}=3.4 \mathrm{~Hz}, 1 \mathrm{H}\right), 4.63$ $\left(\mathrm{dd},{ }^{3} \mathrm{~J}=9.7 \mathrm{~Hz},{ }^{3} \mathrm{~J}=3.3 \mathrm{~Hz}, 1 \mathrm{H}\right), 1.77-1.91(\mathrm{~m}, 2 \mathrm{H}), 1.57-1.75$ $(\mathrm{m}, 1 \mathrm{H}), 0.92-1.02(\mathrm{~m}, 6 \mathrm{H}) ;{ }^{13} \mathrm{C} \mathrm{NMR}\left(100 \mathrm{MHz}, \mathrm{CDCl}_{3}\right): \delta[\mathrm{ppm}]$ $=193.1,143.9,127.8,87.4,72.5,38.2,24.2,23.4,21.2$. Minor isomer (selected signals): ${ }^{1} \mathrm{H}$ NMR $\left(400 \mathrm{MHz}, \mathrm{CDCl}_{3}\right): \delta[\mathrm{ppm}]=$ $6.94\left(\mathrm{dd},{ }^{3} \mathrm{~J}=10.3 \mathrm{~Hz},{ }^{3} \mathrm{~J}=1.6 \mathrm{~Hz}, 1 \mathrm{H}\right), 6.17\left(\mathrm{dd},{ }^{3} \mathrm{~J}=10.3 \mathrm{~Hz}\right.$, $\left.{ }^{4} J=1.6 \mathrm{~Hz}, 1 \mathrm{H}\right), 5.67\left(\mathrm{~d},{ }^{3} J=1.6 \mathrm{~Hz}, 1 \mathrm{H}\right), 4.15$ (dddd, $\left.{ }^{3} \mathrm{~J}=9.6 \mathrm{~Hz},{ }^{3} \mathrm{~J}=3.3 \mathrm{~Hz},{ }^{4} \mathrm{~J}=1.2 \mathrm{~Hz},{ }^{4} \mathrm{~J}=0.4 \mathrm{~Hz}, 1 \mathrm{H}\right) ;{ }^{13} \mathrm{C} \mathrm{NMR}$ $\left(100 \mathrm{MHz}, \mathrm{CDCl}_{3}\right): \delta[\mathrm{ppm}]=147.1,129.0,90.9,82.3$, 39.3. FTIR (ATR): $v\left[\mathrm{~cm}^{-1}\right]=3307(\mathrm{br}), 2954(\mathrm{~m}), 1672(\mathrm{~m}), 1629(\mathrm{w}), 1371$ (m), $1276(\mathrm{~m}), 1157(\mathrm{~m}), 1091(\mathrm{~s}), 1020(\mathrm{~s}), 975(\mathrm{~m}), 898(\mathrm{~m}), 702$ (m). HRMS (ESI): $\mathrm{m} / z[\mathrm{M}-\mathrm{OH}]^{+}$calcd for $\mathrm{C}_{9} \mathrm{H}_{13} \mathrm{O}_{2}: 153.0916$; found: 153.0910 .

6-Hydroxy-2,2-dimethyl-2H-pyran-3(6H)-one (2r): Colorless liquid $\left(15.4 \mathrm{mg}, 108 \mu \mathrm{mol}, 54 \%\right.$ yield). $\mathrm{R}_{f}$ (cyclohexane/ethyl acetate, $2 / 1): 0.33 .{ }^{1} \mathrm{H} \mathrm{NMR}\left(\mathrm{CDCl}_{3}, 400 \mathrm{MHz}\right): \delta[\mathrm{ppm}]=6.87(\mathrm{dd}$, $\left.{ }^{3} J=10.3 \mathrm{~Hz},{ }^{3} \mathrm{~J}=2.2 \mathrm{~Hz}, 1 \mathrm{H}\right), 6.07\left(\mathrm{dd},{ }^{3} \mathrm{~J}=10.3 \mathrm{~Hz},{ }^{4} \mathrm{~J}=1.3 \mathrm{~Hz}\right.$, $1 \mathrm{H}), 5.70-5.68(\mathrm{~m}, 1 \mathrm{H}), 3.38$ (br s, $1 \mathrm{H}), 1.49(\mathrm{~s}, 3 \mathrm{H}), 1.39$ (s, $3 \mathrm{H}) ;{ }^{13} \mathrm{C} \mathrm{NMR}\left(\mathrm{CDCl}_{3}, 100 \mathrm{MHz}\right): \delta[\mathrm{ppm}]=198.9,145.7,126.6$, 88.0, 79.5, 26.6, 23.9. FT-IR (neat, ATR): $v\left[\mathrm{~cm}^{-1}\right]=3402(\mathrm{br})$, $2982(\mathrm{w}), 1681(\mathrm{~s}), 1380(\mathrm{~m}), 1293(\mathrm{~m}), 1238(\mathrm{~m}), 1084(\mathrm{~m}), 1036$ (s), $924(\mathrm{~m})$.

6-Hydroxy-4-methyl-2H-pyran-3(6H)-one (2s): Colorless solid (12.3 mg, $\quad 96 \mu \mathrm{mol}, \quad 48 \%$ yield). $\quad$ M.p.: $\quad 59^{\circ} \mathrm{C} . \quad \mathrm{R}_{f}$ (cyclohexane/ethyl acetate, 2/1): 0.25. ${ }^{1} \mathrm{HNMR}(400 \mathrm{MHz}$. $\left.\mathrm{CDCl}_{3}\right): \delta[\mathrm{ppm}]=6.68\left(\mathrm{dq},{ }^{3} \mathrm{~J}=3.1 \mathrm{~Hz},{ }^{4} \mathrm{~J}=1.4 \mathrm{~Hz}, 1 \mathrm{H}\right)$, 5.55-5.68 (m, $1 \mathrm{H}), 4.56\left(\mathrm{~d},{ }^{2} J=16.9 \mathrm{~Hz}, 1 \mathrm{H}\right), 4.12(\mathrm{~d}$, ${ }^{2} J=16.9 \mathrm{~Hz}, 1 \mathrm{H}$ ), $3.32($ br s, $1 \mathrm{H}), 1.84\left(\mathrm{t},{ }^{4} \mathrm{~J}=1.4 \mathrm{~Hz}, 3 \mathrm{H}\right.$ ); ${ }^{13} \mathrm{C}$ NMR $\left(100 \mathrm{MHz}, \mathrm{CDCl}_{3}\right): \delta[\mathrm{ppm}]=195.3,140.8,135.4,89.2$, 
66.6, 14.5. FT-IR (ATR): $v\left[\mathrm{~cm}^{-1}\right]=3409(\mathrm{br}), 2963(\mathrm{w}), 1665(\mathrm{~s})$, $1434(\mathrm{~m}), 1360(\mathrm{~m}), 1236(\mathrm{~m}), 1144(\mathrm{~m}), 1102(\mathrm{~m}), 990(\mathrm{~s}), 859$ $(\mathrm{m}), 788(\mathrm{~m}), 656(\mathrm{~m})$.

General procedure for the lipase-catalyzed biocatalytic Achmatowicz reaction: The furylcarbinol $(5.0 \mathrm{mmol})$ was dissolved in ethyl acetate $(50 \mathrm{~mL})$, and immobilized lipase $B$ from C. antarctica (105 mg, $1.5 \mathrm{kU})$ and aqueous $\mathrm{H}_{2} \mathrm{O}_{2}(50 \% \mathrm{v} / \mathrm{v}$, $858 \mu \mathrm{L}, 1.02 \mathrm{~g}, 15.0 \mathrm{mmol}$ ) were added. The reaction mixture was placed on an orbital shaker at $40{ }^{\circ} \mathrm{C}(200 \mathrm{rpm})$. After $24 \mathrm{~h}$, phosphate buffer $(15 \mathrm{~mL}, 100 \mathrm{mM}, \mathrm{pH} 7.0)$ and catalase $(5 \mu \mathrm{L})$ were added and the mixture was shaken for additional $15 \mathrm{~min}$. The organic layer was separated and the aqueous layer was extracted with ethyl acetate $(10 \mathrm{~mL})$. The combined organic layers were dried over $\mathrm{Na}_{2} \mathrm{SO}_{4}$ and the volatiles were evaporated under reduced pressure. The pyranone was obtained after purification by column chromatography $\left(\mathrm{SiO}_{2}\right.$, hexanes/ethyl acetate).

6-Hydroxy-2,6-dimethyl-2H-pyran-3(6H)-one (2n): Yellow oil (528 mg, $\quad 3.71 \mathrm{mmol}, \quad 74 \% \quad$ yield; $\alpha / \beta=84: 16) . \quad \mathrm{R}_{f}$ (cyclohexane/ethyl acetate, 2/1): 0.36 . Major isomer: ${ }^{1} \mathrm{H}$ NMR $\left(400 \mathrm{MHz}, \mathrm{CDCl}_{3}\right): \delta[\mathrm{ppm}]=6.80\left(\mathrm{~d},{ }^{3} \mathrm{~J}=10.1 \mathrm{~Hz}, 1 \mathrm{H}\right), 5.99(\mathrm{~d}$, $\left.{ }^{3} J=10.1 \mathrm{~Hz}, 1 \mathrm{H}\right), 4.63\left(\mathrm{q},{ }^{3} \mathrm{~J}=6.7 \mathrm{~Hz}, 1 \mathrm{H}\right), 1.61(\mathrm{~s}, 3 \mathrm{H}), 1.34$ $\left(\mathrm{d},{ }^{3} \mathrm{~J}=6.7 \mathrm{~Hz}, 3 \mathrm{H}\right) ;{ }^{13} \mathrm{C} \mathrm{NMR}\left(100 \mathrm{MHz}, \mathrm{CDCl}_{3}\right): \delta[\mathrm{ppm}]=197.2$, 147.9, 126.1, 92.9, 70.7, 28.9, 15.3. Minor isomer (selected signals): ${ }^{1} \mathrm{H}$ NMR $\left(400 \mathrm{MHz}, \mathrm{CDCl}_{3}\right): \delta[\mathrm{ppm}]=6.86(\mathrm{~d}$, ${ }^{3} \mathrm{~J}=10.2 \mathrm{~Hz}, 1 \mathrm{H}$ ), $4.30\left(\mathrm{q},{ }^{3} \mathrm{~J}=6.8 \mathrm{~Hz}, 1 \mathrm{H}\right), 1.59(\mathrm{~s}, 3 \mathrm{H}), 1.43$ $\left(\mathrm{d},{ }^{3} J=6.8 \mathrm{~Hz}, 3 \mathrm{H}\right) ;{ }^{13} \mathrm{C} \mathrm{NMR}\left(100 \mathrm{MHz}, \mathrm{CDCl}_{3}\right): \delta[\mathrm{ppm}]=150.1$ 126.0, 74.3, 24.3, 17.3. FT-IR (neat, ATR): $v\left[\mathrm{~cm}^{-1}\right]=3302(\mathrm{~m})$, $2987(\mathrm{w}), 1676(\mathrm{~s}), 1444(\mathrm{~m}), 1371(\mathrm{~m}), 1242(\mathrm{~m}), 1145(\mathrm{~m}), 1109$ $(\mathrm{m}), 1070(\mathrm{~m}), 1028(\mathrm{~s}), 939(\mathrm{~m}), 688(\mathrm{~m})$.

6-Hydroxy-2-hexyl-2H-pyran-3(6H)-one (2q): Colorless solid (744 mg, $3.75 \mathrm{mmol}, \quad 75 \% ; \quad \alpha / \beta=75: 25$.). M.p.: $\quad 70^{\circ} \mathrm{C}$. $\mathrm{R}_{f}$ (cyclohexane/ethyl acetate, 2/1): 0.45 . Major isomer: ${ }^{1} \mathrm{H}$ NMR $\left(400 \mathrm{MHz}, \mathrm{CDCl}_{3}\right): \delta[\mathrm{ppm}]=6.88\left(\mathrm{dd},{ }^{3} \mathrm{~J}=10.2 \mathrm{~Hz},{ }^{3} \mathrm{~J}=3.3 \mathrm{~Hz}\right.$, $1 \mathrm{H}), 6.10\left(\mathrm{~d},{ }^{3} \mathrm{~J}=10.2 \mathrm{~Hz}, 1 \mathrm{H}\right), 5.65\left(\mathrm{~d},{ }^{3} \mathrm{~J}=3.3 \mathrm{~Hz}, 1 \mathrm{H}\right), 4.55$ $\left(\mathrm{dd},{ }^{3} \mathrm{~J}=8.1 \mathrm{~Hz},{ }^{3} \mathrm{~J}=3.9 \mathrm{~Hz}, 1 \mathrm{H}\right), 3.08(\mathrm{br} \mathrm{s}, 1 \mathrm{H}), 1.88-1.96(\mathrm{~m}$, $1 \mathrm{H}), 1.65-1.80(\mathrm{~m}, 1 \mathrm{H}), 1.24-1.48(\mathrm{~m}, 8 \mathrm{H}), 0.82-0.92(\mathrm{~m}, 3 \mathrm{H})$; ${ }^{13} \mathrm{C} \mathrm{NMR}\left(100 \mathrm{MHz}, \mathrm{CDCl}_{3}\right): \delta[\mathrm{ppm}]=196.7,144.3,127.8,87.8$, 74.4, 31.8, 29.7, 29.2, 25.0, 22.7, 14.2. Minor isomer (selected signals): ${ }^{1} \mathrm{H} N M R\left(400 \mathrm{MHz}, \mathrm{CDCl}_{3}\right): \delta[\mathrm{ppm}]=6.92(\mathrm{dd}$, $\left.{ }^{3} J=10.2 \mathrm{~Hz},{ }^{3} J=1.5 \mathrm{~Hz}, 1 \mathrm{H}\right), 6.14\left(\mathrm{dd},{ }^{3} J=10.2 \mathrm{~Hz},{ }^{4} J=1.5 \mathrm{~Hz}\right.$, $1 \mathrm{H}$ ), 4.07 (ddd, ${ }^{3} \mathrm{~J}=8.3 \mathrm{~Hz},{ }^{3} \mathrm{~J}=3.9 \mathrm{~Hz},{ }^{4} \mathrm{~J}=1.0 \mathrm{~Hz}, 1 \mathrm{H}$ ), 3.30 (br s, $1 \mathrm{H}) .{ }^{13} \mathrm{C} \mathrm{NMR}\left(100 \mathrm{MHz}, \mathrm{CDCl}_{3}\right): \delta[\mathrm{ppm}]=196.4,147.6$, 128.9, 91.0, 79.1, 30.8, 29.1, 25.2. FT-IR (neat, ATR): $v\left[\mathrm{~cm}^{-1}\right]=$ 3309 (br), 2923 (m), 1673 (s), 1469 (m), 1375 (w), 1275(m), 1157 (m), $1024(\mathrm{~s}), 889(\mathrm{~m}), 784(\mathrm{~m}), 702(\mathrm{~m}), 658(\mathrm{~m})$. HRMS (ESI): $\mathrm{m} / z[\mathrm{M}+\mathrm{Na}]^{+}$calcd for $\mathrm{C}_{11} \mathrm{H}_{18} \mathrm{O}_{3} \mathrm{Na}: 221.1154$; found: 211.1162 .

6-Hydroxy-2,4-dimethyl-2H-pyran-3(6H)-one (2t): Colorless solid $\quad$ (398 mg, $\quad 2.80 \mathrm{mmol}, \quad 56 \% ; \quad \alpha / \beta=88: 12$ ). $\mathrm{R}_{f}$ (cyclohexane/ethyl acetate, 1/1): 0.54 Major isomer: ${ }^{1} \mathrm{H}$ NMR $\left(400 \mathrm{MHz}, \mathrm{CDCl}_{3}\right): \delta[\mathrm{ppm}]=6.86-6.89(\mathrm{~m}, 1 \mathrm{H}), 5.58-5.60(\mathrm{~m}$,
$1 \mathrm{H}$ ), 4.71 (q, ${ }^{3} \mathrm{~J}=6.8 \mathrm{~Hz}, 1 \mathrm{H}$ ), 3.93 (br s, $1 \mathrm{H}$ ), 1.83 (s, 3H), 1.39 $\left(\mathrm{d},{ }^{3} \mathrm{~J}=6.8 \mathrm{~Hz}, 3 \mathrm{H}\right) .{ }^{13} \mathrm{C} \mathrm{NMR}\left(100 \mathrm{MHz}, \mathrm{CDCl}_{3}\right): \delta[\mathrm{ppm}]=197.6$, 139.7, 134.3, 88.1, 70.2, 15.6, 14.7. Minor isomer: ${ }^{1} \mathrm{H}$ NMR $\left(400 \mathrm{MHz}, \mathrm{CDCl}_{3}\right): \delta[\mathrm{ppm}]=6.67-6.69(\mathrm{~m}, 1 \mathrm{H}), 5.61-5.63(\mathrm{~m}, 1 \mathrm{H})$, 4.22-4.13 (m, 1H), $1.82(\mathrm{~s}, 3 \mathrm{H}), 1.44\left(\mathrm{~d},{ }^{3} \mathrm{~J}=6.7 \mathrm{~Hz}, 3 \mathrm{H}\right) .{ }^{13} \mathrm{C}$ $\operatorname{NMR}\left(100 \mathrm{MHz}, \mathrm{CDCl}_{3}\right): \delta[\mathrm{ppm}]=197.2,143.1,135.7,91.0,74.8$, 16.4. FT-IR (neat, ATR): $v\left[\mathrm{~cm}^{-1}\right]=3427(\mathrm{br}), 2984(\mathrm{w}), 1651(\mathrm{~s})$, $1448(\mathrm{~m}), 1367(\mathrm{~m}), 1305$ (w), $1130(\mathrm{~m}), 1091$ (s), $1024(\mathrm{~s}), 995$ (s). HRMS (ESI): $\mathrm{m} / \mathrm{z}[\mathrm{M}+\mathrm{Na}]^{+}$calcd for $\mathrm{C}_{7} \mathrm{H}_{10} \mathrm{O}_{3} \mathrm{Na}$ : 165.0527 ; found: 165.0523 .

Benzyl 6-ethyl-2-hydroxy-5-oxo-5,6-dihydropyridine-1(2H)carboxylate (4): Yellow oil $(82 \mathrm{mg}, \quad 0.58 \mathrm{mmol}, \quad 65 \%$; $\alpha / \beta=80: 20$ ). $R_{f}$ (cyclohexane/ethyl acetate, 3/2): 0.45. Major isomer: ${ }^{1} \mathrm{H} \mathrm{NMR}\left(400 \mathrm{MHz}, \mathrm{CDCl}_{3}\right): \delta[\mathrm{ppm}]=7.38(\mathrm{~m}, 5 \mathrm{H}), 6.91$ (dd, $\left.{ }^{3} J=10.4 \mathrm{~Hz},{ }^{3} J=3.9 \mathrm{~Hz}, 1 \mathrm{H}\right), 6.13 \quad\left(\mathrm{dd},{ }^{3} \mathrm{~J}=10.4 \mathrm{~Hz}\right.$, $\left.{ }^{4} J=1.2 \mathrm{~Hz}, 1 \mathrm{H}\right), 6.02-6.09(\mathrm{~m}, 1 \mathrm{H}), 5.21-5.23(\mathrm{~m}, 2 \mathrm{H}), 4.51(\mathrm{t}$, $\left.{ }^{3} J=7.3 \mathrm{~Hz}, 1 \mathrm{H}\right), 1.80-1.92(\mathrm{~m}, 2 \mathrm{H}), 0.95\left(\mathrm{t},{ }^{3} \mathrm{~J}=7.3 \mathrm{~Hz}, 3 \mathrm{H}\right)$. ${ }^{13} \mathrm{C} \mathrm{NMR}\left(100 \mathrm{MHz}, \mathrm{CDCl}_{3}\right): \delta[\mathrm{ppm}]=195.4,151.5,143.9,135.5$, 128.7,128.6, 128.3, 127.1, 72.2, 68.2, 61.6, 28.9, 10.4. Minor isomer (selected signals): ${ }^{1} \mathrm{H} \mathrm{NMR}\left(400 \mathrm{MHz}, \mathrm{CDCl}_{3}\right): \delta[\mathrm{ppm}]=$ $6.80\left(\mathrm{dd},{ }^{3} \mathrm{~J}=10.5 \mathrm{~Hz},{ }^{3} \mathrm{~J}=3.2 \mathrm{~Hz}, 1 \mathrm{H}\right.$ ). FT-IR (neat, ATR): $v$ $\left[\mathrm{cm}^{-1}\right]=3428(\mathrm{br}), 2969(\mathrm{w}) 1677(\mathrm{~s}), 1426(\mathrm{w}), 1380(\mathrm{~m}), 1316$ (m), $1069(\mathrm{~m}), 1028(\mathrm{~m}), 980(\mathrm{~m}), 907(\mathrm{~m}), 809(\mathrm{w}), 726(\mathrm{~s}), 695$ (s). HRMS (ESI): $\mathrm{m} / z[\mathrm{M}+\mathrm{Na}]^{+}$calcd for $\mathrm{C}_{15} \mathrm{H}_{17} \mathrm{NO}_{4}: 298.1050$; found: 298.1049 .

\section{Acknowledgements}

Financial support by the by the Suomen Akatemia (298250), the Deutsche Forschungsgemeinschaft (DE1599/4-1), the Fonds der Chemischen Industrie and the Dr.-Otto-Röhm-Gedächtnisstiftung is gratefully acknowledged.

Keywords: biocatalysis - peroxidase - ring expansion heterocyclic chemistry $\bullet$ furan

[1] O. Achmatowicz, P. Bukowski, B. Szechner, Z. Zwierzchowska, A. Zamojski, Tetrahedron 1971, 27, 1973-1996.

[2] F. van der Pijl, F. L. van Delft, F. J. P. T. Rutjes, Eur. J. Org. Chem. 2015, 4811-4829; and references therein.

[3] A. K. Ghosh, M. Brindisi, RSC Adv. 2016, 6, 111564-111598; and references therein.

[4] Y. Ma, G. A. O'Doherty, Org. Lett. 2015, 17, 5280-5283.

[5] R. M. M. Mrozowski, Z. M. Sandusky, R. Vemula, B. Wu, Q. Zhang, D. A. Lannigan, G. A. O'Doherty, Org. Lett. 2014, 16, 5996-5999.

[6] O. Achmatowicz, P. Bukowski, Can. J. Chem. 1975, 53, 25242529.

[7] Y. Lefebvre, Tetrahedron Lett. 1972, 2, 133-136.

[6] J. Deska, D. Thiel, E. Gianolio, Synthesis 2015, 47, 3435-3450; and references therein.

[9] C. Asta, D. Schmidt, J. Conrad, B. Förster-Frömme, T. Tolasch, U. Beifuss, RSC Adv. 2013, 3, 19259-19263. 
[10] E. Fernández-Fuego, S. H. H. Younes, S. van Rootselaar, R. W. M. Aben, R. Renirie, R. Wever, D. Holtmann, F. P. J. T. Rutjes, F. Hollmann, ACS Catal. 2016, 6, 5904-5907.

[11] D. Thiel, D. Doknić, J. Deska, Nat. Commun. 2014, 5, 5278.

[12] F. Blume, Y.-C. Liu, D. Thiel, J. Deska, J. Mol. Catal. B Enzym. 2016, 134, 280-284.

[13] Y. Ji, T. Benkovics, G. L. Beutner, C. Sfouggatakis, M. D. Eastgate, D. G. Blackmond, J. Org. Chem. 2015, 80, 16961702.

[14] S. C. Khojasteh-Bakht, W. Chen, L. L. Koenigs, R. M. Peter, S. D. Nelson, Drug Metab. Dispos. 1999, 27, 574-580.

[15] N. Taxak, S. Kaira, P. V. Bharatham, Inorg. Chem. 2013, 52, 13496-13508.

[16] F. van Rantwijk, R. A. Sheldon, Curr. Opin. Biotech. 2000, 11 554-564.

[17] P. R. Ortiz de Montellano, Y. S. Choe, G. DePillis, C. E. Catalano, J. Biol. Chem. 1987, 262, 11641-11646.
[18] R. Wilson, A. P. F. Turner, Biosens. Bioelectron. 1992, 7, 165185.

[19] M. Sundaramoorthy, J. Terner, T. L. Poulos, Structure 1995, 15, 1367-1377.

[20] C. M. Krest, A. Silakov, J. Rittle, T. H. Yosca, E. L. Onderko, J. C. Calixto, M. T. Green, Nat. Chem. 2015, 7, 696-702.

[21] C.-S. Chen, Y. Fujimoto, G. Girdaukas, C. J. Sih, J. Am. Chem. Soc. 1982, 104, 7294-7299.

[22] B. Valderrama, M. Ayala, R. Vazquez-Duhalt, Chem. Biol. 2002, 9, 555-565.

[23] J. R. Cherry, M. H. Lamsa, P. Schneider, J. Vind, A. Svendsen, A. Jones, A. H. Pedersen, Nat. Biotechnol. 1999, 17, 379-384.

[24] F. Blume, P. Sprengart, J. Deska, Synlett, 2018, 29, doi: 10.1055/s-0036-1591889. 
Entry for the Table of Contents (Please choose one layout)

\section{FULL PAPER}<smiles>OCc1ccc(P)o1</smiles>

air + glucose

$\mathrm{OH}$

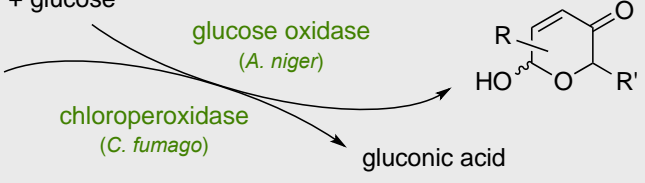

Chloroperoxidase from Caldariomyces fumago catalyzes the selective oxidation of a variety of functionalized furfuryl alcohols in an Achmatowicz-type ring expansion. In combination with glucose oxidase as oxygen-activating biocatalyst, a purely enzymatic, aerobic protocol for the synthesis of 6-hydroxypyranone building blocks is obtained.

\section{Biocatalysis}

Daniel Thiel, Fabian Blume, Christina Jäger, Jan Deska*

Page No. - Page No.

Chloroperoxidase-catalyzed Achmatowicz Rearrangements 